\title{
Role of Genetics and Epigenetics in the Pathogenesis of Alzheimer's Disease and Frontotemporal Dementia
}

\author{
Chiara Fenoglio, Elio Scarpini, Maria Serpente and Daniela Galimberti* \\ Department of Pathophysiology and Transplantation, University of Milan, Centro Dino Ferrari, \\ Fondazione Cá Granda, IRCCS Ospedale Maggiore Policlinico, Milan, Italy
}

Accepted 15 September 2017

\begin{abstract}
Alzheimer's disease (AD) and frontotemporal dementia (FTD) represent the first cause of dementia in senile and pre-senile population, respectively. A percentage of cases have a genetic cause, inherited with an autosomal dominant pattern of transmission. The majority of cases, however, derive from complex interactions between a number of genetic and environmental factors. Gene variants may act as risk or protective factors. Their combination with a variety of environmental exposures may result in increased susceptibility to these diseases or may influence their course. The scenario is even more complicated considering the effect of epigenetics, which encompasses mechanisms able to alter the expression of genes without altering the DNA sequence. In this review, an overview of the current genetic and epigenetic progresses in AD and FTD will be provided, with particular focus on 1) causative genes, 2) genetic risk factors and disease modifiers, and 3) epigenetics, including methylation, non-coding RNAs and chromatin remodeling.
\end{abstract}

Keywords: Alzheimer's disease, epigenetics, frontotemporal dementia, genetics

\section{INTRODUCTION}

Most neurological disorders, including Alzheimer's disease (AD) and frontotemporal dementia (FTD), are multifactorial diseases. Despite a small percentage of these diseases occurring in families with an autosomal dominant pattern of transmission, the majority of cases are sporadic, and derive from complex interactions between a number of genetic and environmental factors. Therefore, these diseases are defined as "multifactorial" or

${ }^{*}$ Correspondence to: Daniela Galimberti, Department of Pathophysiology and Transplantation, University of Milan, Centro Dino Ferrari, Fondazione Cá Granda, IRCCS Ospedale Maggiore Policlinico, Via F. Sforza 35, 20122, Milan, Italy. Tel.: +390255033814; Fax: +390255036580; E-mail: daniela.galimber ti@unimi.it. "complex" [1]. The familial clustering can be explained by recognizing that family members share a greater proportion of their genetic information and environmental exposures than do individuals chosen randomly in the population. Thus, the relatives of an affected individual are more likely to experience the same gene-gene and gene-environment interactions that led to disease in the first place than are individuals who are unrelated to the patient. The multifactorial inheritance pattern represents an interaction between the collective effect of the genotype at one or, more commonly, multiple loci (polygenic or multigenic effects) either to increase or to decrease the susceptibility to the disease, combined with a variety of environmental exposures that may trigger, accelerate, or protect against the disease altered mechanisms. 
The gene-gene interactions in polygenic inheritance may be simply additive or more complicated. Gene-environment interactions, including systematic exposures or chance encounters with environmental factors in one's surroundings, add even more complexity to individual disease risk and the pattern of disease inheritance.

Herein, main genetic variations, either causative or conferring risk for $\mathrm{AD}$ and FTD will be described, together with epigenetic factors.

\section{GENETICS: BASIC CONCEPTS AND METHODOLOGIES}

Genetic background differs from thousands to millions of genetic variants that are the differences in DNA sequences within the genome of individuals in the population. These variations can take many forms, including single nucleotide polymorphisms (SNPs), tandem repeats (short and variable), small insertions and deletions, duplications or deletions that change the copy number of a large segment of a DNA sequence ( $\geq 1 \mathrm{~kb}$ ), i.e., copy number variations (CNVs), and other chromosomal rearrangements such as inversions and translocations (also known as copy-neutral variations) [1-3].

Common variants are synonymous with polymorphisms, defined as genetic variants with a minor allele frequency (MAF) of at least one percent in the population, whereas rare variants have a MAF of less than $1 \%$ [1]. The large majority of genetic variants are hypothesized to be neutral [4], as they do not contribute to phenotypic variation.

Four strategies have been applied so far in genetic studies: genetic linkage analysis, candidate gene studies, genome wide association studies (GWAS), and next generation sequencing (NGS) technology based studies: whole genome sequencing (WGS) and whole exome sequencing (WES).

Linkage analyses were the first kind of strategy used to unravel the genetic basis of Mendelian traits, involving families presenting autosomal dominant inheritance. Genetic linkage studies led to the identification of chromosomal regions associated with the disease segregation, but does not identify the causal gene associated, which requires fine mapping [5].

The candidate gene approach aims to determinate whether frequencies of genetic variants of people with a specific disease differ significantly from a control population. Susceptibility genes are defined when cases and controls showed significant differences in occurring genetic variants frequencies. Candidate gene approach led to the identification of the Apolipoprotein E gene (APOE) risk alleles implicated in late onset AD (LOAD). Thousands of genes were tested in this way on the basis of existing knowledge on disease pathogenesis, quite often giving inconsistent results, particularly because most of the candidate gene association studies could not be replicated, due to the small sample size, which did not allow adequate statistical power [6].

The advent of microarray technology era revolutionized genetics research, allowing the contemporaneous determination of millions of SNPs in thousands of samples. GWAS are based on the testing common genetic variants in a hypothesis-free manner. Thus, it provides information on how common genetic variability confers risk for common diseases [7]. Several susceptibility genes for common neurodegenerative disorders have been revealed by GWAS studies, although the odds ratios associated with these risk alleles are relatively low [8].

Recent advances, collectively referred to as NGS, allowed for high-throughput sequencing, giving massive data results, that need to be analyzed by specific bioinformatics software. Moreover, in opposition to the first generation sequencing, NGS can produce the same genome sequence within a few weeks and with reduced costs. This allows for simultaneous investigation of multiple genes and has been demonstrated to be an effective alternative for establishing the genetic base for Mendelian diseases in the research setting $[9,10]$ and recently also in clinical settings [11, 12]. NGS relies upon multiple, short, overlapping reads of fragmented DNA that can be aligned against a reference genome or assembled "de novo" if no information on the reference genome is available. If just the protein-coding regions are amplified when sequencing all the genes, the method is referred to as WES, whereas when the target is the whole genome, it is known as WGS.

\section{GENETICS OF ALZHEIMER'S DISEASE}

AD is a multifactorial and complex neurodegenerative disorder and the leading cause of dementia among elderly people. Genetically, AD can be subdivided into a rare familial form, accounting for 2-3\% of all patients presenting with autosomal dominant inheritance, and a multifactorial sporadic form in which specific environmental exposures in combination with genetic susceptibility contribute to the 
exacerbation of the disease [1]. Genetically inherited AD usually develops before 65 years of age early onset AD (EOAD), whereas the sporadic type of disease often occurs later in life in individuals older than 65 years and is referred as LOAD [13].

Three genes, discovered thanks to linkage analysis, are responsible for familial AD: Presenilin 1 (PSEN1), Presenilin 2 (PSEN2), and Amyloid precursor protein $(A P P)$. They map on three different chromosomes, but share a common biological pathway related to amyloid processing [14]. A number of variants in these genes have been described, the majority of which play a causal role in the pathogenesis of the disease (see [15] for details).

The proportion of cases of autosomal dominant $\mathrm{AD}$ explained by mutations in these genes is high but vary widely from $12 \%$ to $77 \%$ [16, 17], suggesting that there are additional genetic factors involved in the pathogenesis of EOAD. Recently, thanks to the NGS approach, some new genetic variants were found in small families with unexplained EOAD. Guerreiro et al. [18] identified a missense mutation in NOTCH3 (R1231C), that is a gene previously linked to cerebral autosomal dominant arteriopathy with subcortical infarcts and leukoencephalopathy. Nevertheless, complete screening of NOTCH3 in a cohort of 95 EOAD cases and 95 controls did not reveal any additional pathogenic mutations [18].

Another study [19] identified mutations in the Sortilin related receptor 1 (SORL1) gene in EOAD. This gene encodes a neuronal sorting protein able to bind APP, driving it toward the endosomerecycling pathways [19]. Other studies involving EOAD found association between the Triggering Receptor Expressed on Myeloid cells 2 (TREM2) gene and the risk of develop the disease. TREM2 is an immune phagocytic receptor expressed in brain microglia, able to modulate microglial phagocytosis and inflammatory pathway [20].

By using a NGS WES based approach, an association between TREM 2 variants in exon 2 and EOAD in Caucasian subjects of French origin was identified. In particular, an association between rs75932628T allele $(\mathrm{R} 47 \mathrm{H})$ and the risk of developing the disease was described [21]. The same variant was further confirmed to be a risk factor for EOAD in a recent study [22], which showed that individuals with the R47H variant had significantly earlier symptom onset than individuals without TREM2 variants [22]. TREM2 genetic variability has been investigated also with regard of LOAD susceptibility by different groups. Jonsson et al. [23] found that the rs7593628T in
TREM2 confers a significant threefold increased risk for $\mathrm{AD}$ in a cohort of Icelanders. The same variant was further tested by Guerreiro et al. [24] by WES and was found to cause a five-fold increased risk to develop AD. Furthermore, six additional TREM2 variants were found in $\mathrm{AD}$ but not in controls, highlighting their possible consistent contribution to increase AD risk [25]. In this study, the protective rs728224905 in PLCG2 and the risk variant rs616338 in $A B I 3$ gene were also associated with $\mathrm{AD}$, suggesting an implication of microglial-mediated innate immunity in the pathogenesis of the disease [25].

A recent study [26] identified, by GWAS, a novel missense mutation in phospholipase D family member 3 gene $(P L D 3)$ in an EOAD autopsy-confirmed patient. However, further confirmatory analysis in larger populations of European EOAD did not lead to significant evidence for an enrichment of rare $P L D 3$ variants [26]; therefore the genetic role of $P L D 3$ in $\mathrm{AD}$ remains to be demonstrated. The use of NGS with a target panel able to analyze 10 genes involved in dementia led instead to the identification of novel coding variants in $P S E N 1$, predicted to be pathogenic [27].

Recent GWAS studies [28, 29] confirmed that $A P O E \& 4$ remains the single most important genetic risk factor for $\mathrm{AD}$ (see [30] for review), although about additional ten risk factors emerged recently as strongly associated with LOAD [29, 30]. Notably, the majority of such $\mathrm{AD}$ susceptibility loci (CLU, BINI, $C R 1, A B C A 7, C D 33, E P H A 1)$ have putative functions in lipid metabolism and immune system [30] (Table 1).

Table 1

Causal genes and genetic risk factors for AD

\begin{tabular}{lcl}
\hline Causal genes & Chromosome & Function \\
\hline APP & 21 & Amyloid precursor protein \\
PSEN1 & 14 & APP cleavage \\
PSEN2 & 1 & APP cleavage \\
\hline Risk factors & Chromosome & Function \\
\hline APOE & 19 & Lipid metabolism \\
TREM2 & 6 & Innate immunity; expressed \\
& & by microglia \\
BIN1 & 2 & Nucleocytoplasmic adaptor \\
& & protein \\
CLU & 8 & Lipid metabolism \\
ABCA7 & 19 & Lipid homeostasis in cells of \\
& & the immune system \\
CR1 & 1 & Immune response \\
PICALM & 11 & Membrane metabolism \\
MS4A6A & 11 & Transmembrane protein \\
CD33 & 19 & Membrane antigen \\
$M S 4 A 4 E$ & 11 & Transmembrane protein \\
CD2AP & 6 & Cytoskeleton dynamics \\
\hline
\end{tabular}


A rare variant is the Nicastrin gene, recently identified by NGS as risk factor for LOAD in a Greek population [31].

Lastly, Kohli and colleagues, using WES on 11 affected individuals in a large kindred with apparent autosomal dominant LOAD, found damaging missense mutations in the Tetratricopeptide repeat domain 3 gene (TTC) in all affected individuals [32].

\section{GENETICS OF FRONTOTEMPORAL DEMENTIA: MAJOR CAUSAL GENES}

The majority of FTD cases are sporadic and likely caused by the interaction between genetic and environmental factors. A number of cases, however, present familial aggregation and are inherited in an autosomal dominant fashion, suggesting a genetic cause [32-34]. Up to $40 \%$ of patients have a positive family history, with a diagnosis of dementia in at least one extra family member $[33,35]$. At present, three major causal genes have been identified: Microtubule Associated Protein Tau (MAPT), Progranulin $(G R N)$, and Chromosome 9 Open Reading Frame 72 (C9ORF72). In addition, some rare causal genes have been identified (Table 2).

\section{MAPT}

The first evidence of a genetic cause for familial FTD came from the demonstration of a linkage with chromosome 17q21.2 in autosomal dominantly inherited form of FTD with parkinsonism [36], named FTDP-17. The gene responsible for such association, MAPT, was discovered few years later [37].
MAPT encodes the protein tau, which is involved in microtubule stabilization, assembly, and cytoskeletal dynamics [38]. It is composed of 15 exons and transcribed, by alternative splicing, in 6 different isoforms, all of which play a role in the maintenance of microtubular structure. Any excess of tau protein can be bundled into protein aggregates that fill the cells and induce neurotoxicity. Tau has four repeat domains in the $\mathrm{C}$-terminus, which mediate the interaction with microtubules. These domains are encoded by exons 9-12, in which the majority of pathogenic mutations have been found. In addition, alternative splicing of exon 10 leads to two different isoforms that contain either three (3R) or four (4R) 31-amino acids repeats [39].

The pathology of all MAPT mutations is characterized by the deposition of insoluble aggregated tau proteins within neurons and glial cells in the cerebral cortex and in other brain regions.

To date, more than 40 pathogenic MAPT mutations have been described and classified according to their position in the gene [40], their effects on MAPT transcription, and the type of tauopathy. The frequency of MAPT mutations is highly variable, but in general $M A P T$ mutations are very rare in sporadic patients, whereas in most familial cases the frequency ranges between $5 \%$ and $20 \%$ depending on the geographic distribution [41].

The pathogenic mechanism of each different mutation depends on the type and location of the genetic defect, and affects the normal function of tau, i.e., the stabilization of microtubules promoting their assembly by binding tubulin. Some mutations increase the free cytoplasmic portion of the protein promoting

Table 2

Causal genes and genetic risk factors for FTD

\begin{tabular}{lcl}
\hline Causal genes & Chromosome & Function \\
\hline$M A P T$ & 17 & Microtubule stabilization, assembly and cytoskeletal dynamics \\
GRN & 17 & Inflammation \\
$C 9 O R F 72$ & 9 & Nucleocytoplasmic transport, autophagy, intercellular trafficking \\
$C H M P 2 B$ & 3 & Autophagy, protein trafficking and degradation \\
$V C P-1$ & 9 & Autophagy, protein trafficking and degradation \\
SQSTM1 & 5 & Encodes for p62, autophagy, protein degradation \\
$C H C H D 10$ & 22 & Mitochondrial protein \\
$T B K 1$ & 12 & Autophagy, protein trafficking and degradation \\
$T A R D B P$ & 1 & Encodes for TDP-43, transcription factor \\
$F U S$ & 16 & Encodes for FUS, transcription factor \\
$U B Q L N 2$ & $\mathrm{X}$ & Autophagy, protein trafficking and degradation \\
$T U B A 4 A$ & 2 & Cytoskeletal dynamics \\
Risk Factors & & \\
$T M E M 106 B$ & 11 & Transmembrane protein \\
GRN & 17 & Inflammation \\
$R A B 8 / C T S C$ & 11 & Lysosomal biology and protein trafficking \\
$H L A$ & 6 & Immune system \\
\hline
\end{tabular}


tau aggregation, while others lead to an aberrant phosphorylation of tau protein, which damages microtubule stabilization [41]. Regarding mutations localized in the donor splicing site following exon 10 , it was shown that these intronic mutations increase the inclusion of $M A P T$ exon 10 by destabilizing the stem-loop structure that spans the splice site of exon 10 , resulting in an increased production of $4 \mathrm{R}$ tau. Mutations in the acceptor splicing site following exon 10 lead to an enhanced inclusion of this exon [42].

Alternatively, other mutations affect the alternative splicing, thus producing altered ratios of the different isoforms (3R/4R tau). Most of missense mutations, such as the p.P301L mutation, reduce the ability of tau to bind microtubules leading to a decreased tau capacity to promote microtubules assembly [43]. Moreover, it was observed in in vitro studies that several coding mutations accelerate the aggregation of tau [44]. In 2009, Rovelet-Lecrux and coworkers identified a heterozygous $17.3 \mathrm{~Kb}$ deletion responsible for the removal of exons 6-9 of MAPT in one FTD patient [45]. This deletion caused the loss of the first microtubule binding domain and a decrease in the binding abilities of tau to the microtubules. The same group reported a $439 \mathrm{~Kb}$ duplication in the region encompassing CRHRl, MAPT, and saithoin (STH) in one patient affected by behavioral and amnestic disorders [46].

The clinical presentation in MAPT mutation carriers is heterogeneous, but behavioral changes, semantic impairment, episodic memory decline, and parkinsonism have been proposed as key clinical features. From the pathological point of view, patients present atrophy of the frontotemporal lobes and basal ganglia and variable presences of tau-positive inclusions, typical of FTLD-tau [47].

\section{GRN}

After the discovery of MAPT as causal gene for FTDP-17, there were still numerous autosomal dominant FTD cases genetically linked to the same chromosomal region of $M A P T$ (chr17q21), without any mutation in $M A P T$, in spite of an extensive fine mapping of the gene. A small region rich in genes, localized approximately $6.2 \mathrm{Mb}$ in physical distance to MAPT locus, had been recognized as that one containing the gene responsible for the disease in these families. The first identified mutation in $G R N$, identified in 2006, consisted of a 4-bp insertion of CTGC between coding nucleotides 90 and 91, causing a frameshift and premature termination in progranulin
(C31LfsX34) [48]. In a parallel study, Cruts and coworkers found at the same time another mutation of five base pairs into the intron following the first non-coding exon of GRN (IVS1+5G>C) [49]. This mutation causes the splicing out of the intron 0 , leading the retention of mRNA within the nucleus and its degradation.

$G R N$ mutations were subsequently found to account for 5-20\% of FTD patients with positive family history and $1-5 \%$ of apparently sporadic patients [50].

$G R N$ encodes for the growth regulation factor named progranulin. Progranulin is an $88 \mathrm{kDa}$ secreted glycoprotein, which in brain is expressed by neurons and microglia [51]. Its expression is low in early development and increases with age. The protein is composed by seven and one half cysteine-rich granulin domains and can be cleaved by several proteases into $6 \mathrm{KDa}$ units called granulins. It belongs to a family of proteins involved in multiple biological functions, including development, wound repair, and inflammation, by activating signaling cascades that control cell cycle progression and cell motility [51].

Since the original identification of null-mutations in FTLD, more than 70 different mutations have been described so far. Most of the known pathogenic GRN mutations, particularly frameshift, splice-site, and nonsense mutations, are predicted to result in a premature stop codon. The resulting aberrant mRNA is degraded through the process of nonsense mediated decay, leading to haploinsufficiency [52]. Also rare partial deletions and a complete deletion of the gene have been described [53].

At neuropathological examination, $G R N$-mutated FTD cases displayed ubiquitin-positive, tau-negative inclusions (FTLD-U) similar to the microvacuolartype still observed in a large proportion of apparently sporadic FTD, that were different from the taupositive inclusions typical of MAPT mutated cases. Truncated and hyperphosphorylated isoforms of the TAR DNA binding Protein (TDP-43) were recognized as main components of the ubiquitin-positive inclusions typical of the GRN mutated families, as well as of idiopathic FTD and of a proportion of cases of amyotrophic lateral sclerosis (ALS) [54]. According to the novel neuropathological classification of FTLD-TDP pathology in FTD [55], TDP-43 neuropathological subtype $\mathrm{A}$ is consistently found in association with $G R N$-mutated cases.

A collaborative study [53] analyzing GRN mutations in 434 patients estimates a frequency of $6.9 \%$ of all included FTD-spectrum cases. About $56 \%$ of such 
cases was represented by FTD subjects with ubiquitinated inclusions at the neuropathology (FTD-U) with a positive family history of FTD.

From the clinical point of view, mutations in GRN are associated with extremely heterogeneous phenotypes, but the main clinical diagnosis is FTD following by diagnosis of primary progressive aphasia [56]. Language impairment seems to be more relevant as the disease progresses. About $40 \%$ of patients have parkinsonism, and episodic memory impairment is frequently observed, leading to a clinical diagnosis of AD in some cases [57]. Although rarely, an overlap between psychiatric disorders and genetically determined FTD can occur, as shown by Rainero et al. [58], who described a patient with heterosexual pedophilia who was a carrier of a GRN mutation and developed FTD over time, and by Cerami et al. [59], who reported two clinically different, apparently sporadic FTD cases sharing the Thr272fs GRN mutation, who had a premorbid bipolar disorder history.

The penetrance for GRN mutations is age dependent with only $50 \%$ of $G R N$ mutation carriers affected at the age of 60 and $90 \%$ of mutation carriers affected at 70 years of age. Age at disease onset is extremely wide, even in the same family, ranging from 47 to 79 years [60]. In a large Calabrian family harboring a heterozygous c.1145insA mutation, the age at onset ranged from 35 to 87 years whereas the age of death was from 56 to 87 years [61]. In that family, the clinical presentation was homogenous; all of affected members had clinical diagnosis of FTD with subsequent language impairment.

A major contribution to achieve a correct diagnosis independent of the phenotypic presentation is the demonstration that progranulin plasma levels are extremely low in GRN mutation carriers, even in asymptomatic subjects [62, 63].

Regarding the function of progranulin, Pickford et al. [64] demonstrated, in an in vitro model, that it has chemotactic properties toward cultured mouse neurons. In addition, progranulin-treated primary neurons secrete a number of cytokines and chemokines, particularly those involved in proliferation (i.e., IL-4), and, importantly, induce microglia to switch from a pro-inflammatory to an anti-inflammatory phenotype [64]. Another recent observation is that progranulin binds the Tumor Necrosis Factor Receptor (TNFR)2, that is expressed specifically in neuronal subtypes and glial cells in the brain, leading to an anti-inflammatory cascade [65].
Abnormalities of several cytokines and chemokines has been observed in cerebrospinal fluid (CSF) of GRN carriers compared with controls [66], suggesting an imbalance of specific inflammatory factors possibly related to $G R N$ haploinsufficiency.

\section{C9ORF72}

One of the most intriguing discoveries in the genetics of FTD has been the investigation of FTD/motor neuron disease (MND) families linked to a locus on chromosome 9q21-22. The first evidence of linkage with this locus comes from a study carried out in families with autosomal dominant FTD-MND [67]. Additional data confirmed the linkage to chr9q21-22 in FTD-MND families [68], until, in 2011, two international groups identified the gene responsible for the disease in this locus, C9ORF72 [69, 70]. The mutation consists of a large hexanucleotide (GGGGCC) repeat expansion in the first intron of the gene.

In healthy subjects, most individuals carry between 2 and 20 repeats, but FTD and ALS patients had from 100 to also $1000 \mathrm{~s}$ of copies of repeats. The minimum repeat length to confer risk of disease is unknown, probably due to the presence of somatic mosaicism. In fact, the length of repeats is different between tissues even in the same individual and this phenomenon complicates genotype-phenotype correlation studies [71].

C9ORF72 repeat expansion is the most common cause of FTD (with or without ALS) worldwide. There is a particular high frequency in a Finland population, probably due to a common founder. Studies in Asian cohorts have reported instead much lower frequencies [72].

Clinical phenotypes are very variable [73] as well as the age at onset and disease duration; in fact, age at onset can range between 27 and 83 years and disease duration from 1 to 22 years. The most common clinical presentation is FTD, ALS, or both. As mentioned above, in families where FTD-ALS is the clinical phenotype, the C9ORF72 repeat expansion is very common, explaining the disease in more than $50 \%$ of families [74]. FTD patients present behavioral disturbances, whereas language impairment is less commonly observed [75]. In addition to classical behavioral presentations, such as apathy, disinhibition, socially inappropriate conduct, and loss of empathy, C9ORF72 expansion carriers present a high frequency of hallucinations, psychosis, and delusions [76], which lead to a primary diagnosis of schizophrenia and bipolar disorders [77, 78]. Sometimes patients 
have episodic memory problems at the beginning of the disease course, receiving a primary diagnosis of $\mathrm{AD}[76,79]$. Less than $1 \%$ of clinically diagnosed AD patients carry a C9ORF72 expansion with TDP43 pathology [79]. Other studies [80] found no C9ORF72 expansions in $\mathrm{AD}$ patients, suggesting the total frequency of $C 9 O R F 72$ positive cases in $\mathrm{AD}$ is very rare $(<1 \%)$. Most likely, there is no association between $\mathrm{AD}$ and C9ORF72. Likely, some $\mathrm{AD}$ cases have been misdiagnosed or some expansions are not big enough to be causal. Early-parkinsonism has also been reported in C9ORF72 expansion carriers, although very rarely in $M A P T$ and $G R N$ mutation carriers [76].

From a neuropathological point of view, postmortem examination showed that C9ORF72 expansion carriers present TDP-43 positive inclusions in different brain areas. Most patients present with FTLD-TDP type A or B [55]. In addition, they have neuronal inclusions in the cerebellar granule cell layer, hippocampal pyramidal neurons, and other anatomic sites that are positive for ubiquitin and p62 proteins. These inclusions are composed by dipeptide repeat proteins (DPRs), translated from the GGGGCC repeat through unconventional repeatassociated non-ATG translation. Poly-GP, Poly-GA, and Poly-GR are generated from sense strand and detected in hippocampus and cerebellum of expansion carriers [81]. Normal C $9 O R F 72$ functions were reported to be involved in the nucleocytoplasmic transport, autophagy, intercellular trafficking, and TDP-43 aggregation (see [82] for review).

Reddy et al. [83] demonstrated that the r(GGGGCC)n RNA forms extremely stable Gquadruplex structures, which theoretically may affect promoter activity, genetic instability, RNA splicing, translation and neurite mRNA localization.

Moreover, several studies, conducted in derived cells and tissue of patients, demonstrated that these foci are able to sequester RNA binding protein, including hnRNP h, hnRNP A1, and SC35, affecting the mRNA nuclear transport system [84]. However, the clear mechanism linking RNA foci and sequestered proteins to neurodegeneration has not been fully understood. Together with the formation of RNA foci and DPR, another suggested pathological mechanism of the C9ORF72 expansion is gene downregulation due to C9ORF72 methylation [85].

In cultured cells and primary neurons, Poly-GA overexpression led to the generation of p62-positive inclusions and neurotoxicity attributed to impaired ubiquitin proteasome function [86]. On the other hand, arginine-rich dipeptide (poly-GR and poly$\mathrm{PR})$ led to the formation of nucleolar inclusions in fly models [87]. Since the clinical utility as well as the significance and the temporal course of DPRs in the pathogenesis of the disease is still unclear, Lehmer et al. [88] established a poly-GP immunoassay from CSF in order to identify and characterize C9ORF72 patients. Intriguingly, they observed Poly-GPCSF levels were already detectable in C9ORF72 asymptomatic carriers compared to healthy subjects and these levels are similar in symptomatic expansion carriers, demonstrating a possible use as a diagnostic biomarker in addition to genetic screening [88].

\section{GENETICS OF FRONTOTEMPORAL DEMENTIA: RARE CAUSAL GENES}

\section{CHMP2B}

Few FTLD families display mutations in the charged multivesicular body protein 2B gene $(C H M P 2 B)$, which encodes a component of the heteromeric ESCRT III complex, involved in the endosomal trafficking and degradation [89]. $C H M P 2 B$ is involved in sorting and trafficking surface receptors or proteins into intraluminal vesicles for lysosomal degradation and binding the Vps4 protein responsible for the dissociation of ESCRT components [90]. The first mutation in $C H M P 2 B$ was identified in one large kindred from Denmark [91]. Behavioral and cognitive impairment associated with extrapyramidal and pyramidal signs are the main clinical manifestations in $C H M P 2 B$.

All mutations described (missense and truncation mutations) show a common mechanism of action: the deletion of the C-terminus of the protein with the loss of the Vsp-4 binding domain [90]. This causes the accumulation of mutated CHMP2B on the endosomal membrane and prevent the recruitment of other proteins necessary for endosomal fusion with lysosomal. This phenomenon leads to the impairment of the late endosomal trafficking and contributes to neurodegenerative processes in FTD [91]. This can be observed as enlarged and abnormal endosomal structures in postmortem brain tissue from patients [92]. From a histological point of view, patients with $C H M P 2 B$ mutations present FTLD-U with ubiquitin- and p62positive but TDP-43-negative neuronal cytoplasmic inclusions [93]. 


\section{VCP-1 and SQSTMI}

Mutations in the Valosin Containg Protein gene $(V C P)$ were firstly described as cause of hereditary inclusion body myopathy with Paget's disease of the bone (PDB) and FTD [94]. Myopathy is the most frequent clinical symptom, present in about $90 \%$ of affected subjects, whereas FTD is seen in about 33\%, usually many years after the onset of muscle symptoms. From a histological point of view, brain tissues of patients carrying VCP mutations are characterized by FTLD-TDP type D pathology with TDP43 and p62 positive inclusions within neuronal nuclei [95].

VCP-1 encodes a monomeric protein composed of 806 aminoacids. It is known as a regulator of many cellular processes, such as ubiquitin-dependent protein quality control, labeling proteins for degradation, and coordination of the removal of protein aggregates via multivesicular body formation [96].

Another gene involved in the mechanism of protein degradation as well as in FTLD pathogenesis is Sequestosome 1 gene (SQSTM1). This gene encodes for p62 protein, a connector between ubiquitinated proteins and autophagy receptor or proteasome degradation pathways [97]. Mutations in SQSTM1 were first described in PDB and are responsible for around 30\% of familial PDB cases (see [98] for review). In 2014, Van der Zee et al. published a large-scale resequencing study in an FTLD cohort of patients and identified a number of mutations in the C-terminal of the gene that is involved in the binding with ubiquitinated proteins [99].

\section{CHCHD10}

A coiled-coil-helix-coiled-coil-helix domain containing 10 (CHCHD10) gene encodes a mitochondrial protein that is enriched at cristae junctions in the intermembrane space. By exome sequencing, it was possible to identify the first pathogenic mutation, p.S59L, in an atypical family with late onset MND, FTD, cerebellar ataxia, and mitochondrial myopathy [100]. Subsequent genetic studies identified additional potential pathogenic mutation in FTD and ALS patients with $1-3 \%$ frequency [101]. Very recently, Perrone et al. identified a novel nonsense mutation (p.Gln108*) in a patient with atypical clinical FTD and pathology-confirmed Parkinson's disease (1/459, $0.22 \%$ ) leading to loss of transcript. They further observed three previously described missense variants (p.Pro34Ser, p.Pro80Leu, and p.Pro96Thr) that were also present in the matched control series [102].
$T B K 1$

In 2015, a large exome sequencing case-control study identified mutations in the TANK binding kinase 1 gene $(T B K 1)$ in sporadic ALS cohort of patients [103]. Subsequent studied showed TBK1 loss of function mutations in families with FTD-ALS but also in clinical FTD and pathologically confirmed FTLD-TDP even in the absence of motor neuron disease [104]. The majority of mutations identified are loss-of-function mutations leading to a decrease $50 \%$ of $T B K 1$ expression. Missense mutations instead impair the binding of TBK1 to optineurin (OPTN). As VCP or p62, TBK1 is also involved in protein degradation and autophagy mechanisms. In fact, it phosphorylates p62 and OPTN, another member of the autophagy pathway. In 2015, Potteir et al. discovered, in a pathologically confirmed cohort of patients, one heterozygous mutation and one deletion in OPTN as well as a nonsense mutation in TBKl suggesting that both genes contribute to FTLD-TDP etiology [104].

\section{TARDBP}

TARDBP encodes for TDP-43 protein, which is localized in the nucleus of the cell, where it is able to form heterogeneous nuclear ribonucleoprotein (hnRNP) complexes with several functions, such as RNA regulation, mRNA stability and transport, and splicing control. A link between FTLD and ALS and TDP-43 was supported by the evidence that TDP-43 regulate axon growth in vivo and in vitro suggesting that the capacity of motor neuron to produce and maintain axons is compromised by TDP-43 dysregulation [105].

\section{FUS}

Similar to TDP-43, Fused in sarcoma (FUS) is highly conserved and ubiquitously expressed gene. FUS is a component of the hnRNP complex and involved in RNA transport in and out of the nucleus, RNA splicing, and DNA/RNA metabolism [106]. In 2009, FUS mutations were discovered to be the cause of $3 \%$ of familial ALS. They are mostly located in the C-terminal of the protein, particularly in the nuclear localization sequence, resulting in an impairment of transportin (TRN1)-mediated nuclear import of FUS [106]. Neuropathologically, ALS patients with FUS mutations display abnormal cytoplasmic neuronal and glial inclusions positive for FUS. However, in 
some FTLD-FUS patients, no FUS mutations have been identified.

\section{UBQLN2}

$U B Q L N 2$ is involved in a rare form of chromosome X-linked familial ALS and FTLD-ALS [107]. Mutations are located in proline residues in the highly conserved PXXP repeat domain involved in the degradation of misfolded proteins via ubiquitin proteasome system and autophagy.

\section{TUBA4A}

TUBA4A encodes 1 of 8 human a-tubulins, which polymerize with $b$-tubulins to form the microtubule cytoskeleton. TUBA4A mutations have primarily been associated with ALS, although some patients also had cognitive involvement ranging from mild cognitive impairment to FTD. In TUBA4A, 10 missense, 1 nonsense, and 1 splice donor site mutation have been identified in both sporadic and familial ALS patients, with some also presenting with FTD [102].

\section{GENETICS OF FRONTOTEMPORAL DEMENTIA: GENETIC MODIFIERS}

In addition to genes mentioned above and generally involved in familial autosomal dominant transmission, several genetic risk factors have been studied. The most important and replicated is the transmembrane protein $106 \mathrm{~b}$ gene (TMEM106B). In 2010, Van Deerlin and coworkers published the first GWAs on 515 FTD patients with TDP-43 pathology; they identified a possible susceptibility locus, which encompasses TMEM106B gene on chromosome $7 \mathrm{p} 21$ [108]. In particular, the study identified three associated single nucleotide polymorphisms (SNPs), rs102004, rs6966915 and rs1990622, which are correlated with an increase of TMEM106B expression level [108]. Several subsequent studies showed that the highest association with TMEM106B locus was found in patients with GRN mutations with TDP43 pathology [109, 110]. In GRN mutation carriers, the presence of protective C allele of SNP rs1990622, protects these patients from developing FTD [110]. The protective effects of TMEM106B are not confined to carriers of $G R N$ mutations but also extend to C9ORF72 carriers $[111,112]$. TMEM106b is a glycosylated type 2-membrane protein that localized to late endosomes and lysosomes where it seems to have an important function. Over-expression of TMEM106b in cell cultures showed an aberrant vacuole formation and an impairment of endolysosomal pathway [113].

Common SNPs in the major causal genes have been studied to determine their association as FTD risk factors. For example, rs5848, located in 3'UTR of the $G R N$ gene in a putative miRNA binding site, has been investigated. Unfortunately, its role remains unclear with significant association in initial series of FTD-TDP43 patients but not in subsequent series of clinical patients [114]. More recently, a two-stage GWAS identified the HLA locus at chromosome 6p21.3 and a locus at chromosome 11q14 encompassing $R A B 38$ and cathepsin C (CTSC) [115]. These two gene are especially associated with FTD and an association was observed between the top SNP at $R A B 8 / C T S C$ locus and a 50\% reduction of RAB8 levels in the blood of patients suggesting that a loss of RAB8 function may play a role in the development of FTD. RAB8 is a protein involved in the regulation of lysosomal biology and protein trafficking. The HLA locus, instead, suggests a link between FTD and immune system [115].

\section{EPIGENETICS}

Epigenetics is focused on the investigation of mechanisms able to influence the expression of genes without altering the DNA sequence. DNA methylation, chromatin remodeling, and non-coding RNAs (ncRNAs) are the three most investigated epigenetic modifications [116]. Epigenetic processes are able to regulate DNA replication and repair, RNA transcription, and chromatin conformation, that influence in turn transcriptional regulation and protein translation.

\section{Methylation}

DNA methylation is the best characterized epigenetic modification that involves the addition of a methyl group to the carbon-5 of a cytosine residue in DNA and is carried out by one of the several DNA methyltranferase (DNMT) enzymes. DNMT1 is the enzyme responsible for the maintenance of DNA methylation patterns during DNA replication. It localizes to the DNA replication fork, where it methylates nascent DNA strands at the same locations as in the template strand [117]. DNMT3a and DNMT3b are involved in the de novo methylation of unmethylated and hemimethylated sites in nuclear and mitochondrial DNA, respectively [117, 118]. 
In mammals, DNA methylation occurs predominantly at $\mathrm{CpG}$ sites-locations, where a cytosine nucleotide is followed by a guanine nucleotide. $\mathrm{CpG}$ sites can occur in concentrations of up to several hundred dinucleotide repeats, called $\mathrm{CpG}$ islands, which are frequently found in gene promoters. The methylation or hypermethylation of $\mathrm{CpG}$ islands usually prevents the expression of the downstream gene [119]. DNA methylation is currently the best understood epigenetic mechanisms, and is known to have a crucial role in normal development, cell proliferation, and genome stability [120]. In addition, non-CpG methylation may happen in stem cells and neurons [121].

Early epigenetic investigations related to $\mathrm{AD}$ focused on DNA methylation, finding non AD specific hypomethylation of the APP gene promoter region in one patient [122].

More recent studies support an overall reduction in DNA methylation in AD patients thus highlighting the importance of DNA methylation in AD [123]. Interestingly $A \beta$ has also been implicated as a trigger of epigenetic changes as it was found that $A \beta$ induces global DNA hypomethylation [124]. Moreover, a DNA methylome paper found genes with altered methylation in AD brains [125].

Tau gene expression is also subject to complex epigenetic regulation, involving differentially methylated binding sites for transcription factors [126].

Recently, Bollati and colleagues investigated the methylation status of repetitive elements in blood, including Arthrobacter luteus elements (Alu) blood, long interspersed element 1 (LINE-1), and satellite- $\alpha$ (SAT- $\alpha$ ), that comprise a wide portion of the human genome and are known to contain large numbers of CpG sites. They found that LINE-1 methylation was increased in AD patients and that enhanced LINE-1 methylation was associated with a better cognitive performance in AD patients [127].

Regarding FTD, two studies analyzed the GRN promoter methylation in relation to its ability to regulate progranulin expression. They found that increased methylation in FTD subjects negatively correlates with GRN mRNA levels [128, 129].

A recent GWAS on DNA methylation pattern in peripheral blood of patients with FTD and progressive supranuclear palsy compared to healthy subjects found a specific methylation signature associated pathologically with tauopathy, suggesting this signature as a risk factor for neurodegeneration [130].

Regarding the C9ORF72 expansion, it was suggested that the length of the repeat might influence the level of DNA methylation at the C9ORF72 promoter. This process was found in a family from Canada with the father carrying an intermediate length allele, about 70 repeats, with an unmethylated C9ORF72 promoter, that expanded to about 1750 repeats in his children. The expanded allele carried by the four children was characterized by $C 9 O R F 72$ promoter hypermethylation and associated with reduced C9ORF72 expression [131]. Recent findings demonstrated that DNA hypermethylation was found in the 5' $\mathrm{CpG}$ region ( $\sim 36 \%$ ALS cases), as well as the C9ORF72 repeat itself in both ALS and FTD patients $(\sim 100 \%)$ [132, 133].

\section{$n c R N A s$}

It was widely believed in the past that most of the human genome consisted in "non-functional" DNA. It was later discovered that almost the whole genome is transcribed, but that just about $2 \%$ in translated into proteins [134].

It is now instead ascertained that most of this "junk" is functional and composed by ncRNA, whose signaling and editing is able to play a crucial role in chromatin and nuclear structure. In particular, ncRNAs are involved in epigenetic regulation by recruiting chromatin-modifying complexes. ncRNAs operate through repressive control but have also the potential to act as gene activators [134].

ncRNAs comprise small RNAs (sRNAs) of less than 200 nucleotides and long non coding RNA (lncRNAs) of more than 200 nucleotides. sRNAs are further subdivided as micro (mi)RNAs, short interfering (si)RNAs, and PIWI-associated (pi)RNAs, whereas lncRNA are categorized according to their direction and position of their transcription in: antisense, intergenic, exonic, intronic, overlapping [135].

miRNAs are single stranded, non-coding small RNAs that are abundant in plants and animals, and are conserved across species [136]. The raw transcripts undergo several nuclear and cytoplasmic post-translation processing steps to generate mature, functional miRNAs. In the cytoplasm, mature miRNAs associate with other proteins to form the RNA-Induced Silencing Complex (RISC), enabling the miRNA to imperfectly pair with cognate miRNA transcripts. The target mRNA is then degraded by the RISC, preventing its translation into protein [137, 138]. miRNA-mediated repression of translation is involved in many cellular processes, such as differentiation, proliferation, and apoptosis, as well as other key cellular mechanisms [139, 140]. 
It is now well established that altered RNA processing could act as a contributing factor to several neurological conditions including aging-related neurodegenerative diseases such as AD, FTD, ALS, and Parkinson's disease [141-143].

In $\mathrm{AD}$, the implication of miRNAs in $\mathrm{A} \beta$ production, via BACE1 modulation, and in tau phosphorylation, that leads to hyperphosphorylated neurofibrillary tangle formation, has been demonstrated [142].

Altered miRNA signatures were also identified in $\mathrm{AD}$ and FTD. In particular, several miRNAs have identified differentially expressed in postmortem tissue, blood, and CSF that also differ by disease stage $[145,146]$.

Regarding lncRNAs, they also have been involved in neurodegenerative diseases [146].

These ncRNAs are involved in different functions; they act as scaffolds for chromatin modifiers and nuclear paraspeckles, as transcriptional coregulators, and even as decoys for other RNAs [145]. Dysregulations in lncRNAs can influence any one of these processes, thus contributing to neurodegeneration. IncRNAs associated with disease condition can post-transcriptionally increase gene expression, as it happens with the IncRNA BACE1-antisense whose expression is selectively increased in $\mathrm{AD}$ brains and competes with miR-545-5p binding to stabilize BACE1 mRNA. This will finally result in increased expression of BACE1 that contribute to the formation of the toxic $A \beta$ peptides that is a major hallmark for $\mathrm{AD}$ [146].

Another lncRNA, BC200, likely plays a role in $\mathrm{AD}$ as increased levels were found in specific brain regions mostly affected by AD, such as the Brodmann's area 9 [147]. MALAT1 and NEAT1 are other two lncRNAs very important for splicing and synapse formation [148, 149].

\section{Chromatin remodeling}

In mammalian cells, histone proteins interact with DNA to form chromatin, the packaged form of DNA. Histones are octamer consisting of two copies of each of the four histone proteins: H2A, H2B, H3, and H4. Each histone octamer constitutes in $146 \mathrm{bp}$ of the DNA stand wound around it to make up one nucleosome, which is the basic unit of chromatin. Histone proteins can be modified by post translational changes, including: acetylation, methylation, phosphorylation, ubiquitination, and citrullination. These histone modifications induce changes to the structure of chromatin and thereby affect the accessibility of the DNA strand to transcriptional enzymes, resulting in activation or repression of genes associated with the modified histone [150]. The best-understood histone modification is acetylation, which is mediated by histone acetyltransferases and deacetylases [151]. Acetylation of histones is usually associated with upregulated transcriptional activity of the associated gene, whereas deacetylation of histones to transcriptional silencing [152].

Histone acetylation was found to be largely decreased in the temporal lobe of $\mathrm{AD}$ patients compared to controls and in mouse models of AD [153]. Moreover, increased $\mathrm{H} 3$ acetylation at the promoter region of the $\mathrm{BACE} 1$ gene in $\mathrm{AD}$ patients was found [153].

Besides acetylation, different forms of histone methylation exist [154], and may be linked to neurodegenerative diseases.

\section{CONCLUSIONS}

Herein, we provided an overview of the current genetic and epigenetic progresses in AD and FTD. We reviewed current knowledge on causative genes and altered mechanisms leading to the two diseases, genetic risk factors and disease modifiers shown to influence the age at onset and clinical course of the diseases, and the role of epigenetics, including methylation, non-coding RNAs, and chromatin remodeling, in influencing gene expression. Data obtained so far suggest a crucial role of microglia and immunity in $\mathrm{AD}$ and a role of autophagy and proteasomal degradation in FTD. Future challenges will be a better understanding of the interplay among genetic and epigenetic factors in order to correlate pathogenic mechanisms with clinical phenotypes and pave the way for novel therapeutic approaches such as miRNA mimics or miRNA antagonists (antagomirs), specifically designed to either reverse the downregulation or upregulation of disease-associated miRNAs.

\section{DISCLOSURE STATEMENT}

Authors' disclosures available online (https:// www.j-alz.com/manuscript-disclosures/17-0702r2).

\section{REFERENCES}

[1] Frazer KA, Murray SS, Schork NJ, Topol EJ (2009) Human genetic variation and its contribution to complex traits. Nat Rev Genet 10, 241-251. 
[2] Nakamura Y (2009) DNA variations in human and medical genetics: 25 years of my experience. J Hum Genet 54, 1-8.

[3] Ku CS, Loy EY, Salim A, Pawitan Y, Chia KS (2010) The discovery of human genetic variations and their use as disease markers: Past, present and future. J Hum Genet 55, 403-415.

[4] Kimura, M (1968) Evolutionary rate at the molecular level. Nature 217, 624-626.

[5] Dawn Teare M, Barrett JH (2005) Genetic linkage studies. Lancet 366, 1036-1044.

[6] Hattersley AT, McCarthy MI (2005) A question of standards: What makes a good genetic association study? Lancet 366, 1315-1323.

[7] Simón-Sánchez J, Singleton A (2008) Genome-wide association studies in neurological disorders. Lancet Neurol 7, 1067-1072.

[8] Pritchard JK (2001) Are rare variants responsible for susceptibility to complex diseases? Am J Hum Genet 69, 124-137.

[9] Bamshad MJ, Ng SB, Bigham AW, Tabor HK, Emond MJ, Nickerson DA, Shendure J (2011) Exome sequencing as a tool for Mendelian disease gene discovery. Nat Rev Genet 12, 745-755.

[10] Boycott KM, Vanstone MR, Bulman DE, MacKenzie AE (2013) Rare-disease genetics in the era of next-generation sequencing: Discovery to translation. Nat Rev Genet 14, 681-691.

[11] Yang Y, Muzny DM, Reid JG, Bainbridge MN, Willis A, Ward PA, Braxton A, Beuten J, Xia F, Niu Z, Hardison M, Person R, Bekheirnia MR, Leduc MS, Kirby A, Pham P, Scull J, Wang M, Ding Y, Plon SE, Lupski JR, Beaudet AL, Gibbs RA, Eng CM (2013) Clinical whole-exome sequencing for the diagnosis of Mendelian disorders. N Engl J Med 369, 1502-1511.

[12] Yang Y, Muzny DM, Xia F, Niu Z, Person R, Ding Y, Ward P, Braxton A, Wang M, Buhay C, Veeraraghavan N, Hawes A, Chiang T, Leduc M, Beuten J, Zhang J, He W, Scull J, Willis A, Landsverk M, Craigen WJ, Bekheirnia MR, Stray-Pedersen A, Liu P, Wen S, Alcaraz W, Cui H, Walkiewicz M, Reid J, Bainbridge M, Patel A, Boerwinkle E, Beaudet AL, Lupski JR, Plon SE, Gibbs RA, Eng CM (2014) Molecular findings among patients referred for clinical whole-exome sequencing. JAMA 312, 1870-1879.

[13] Blennow K, de Leon MJ, Zetterberg H (2006) Alzheimer's disease. Lancet 368, 387-403.

[14] Lill CM, Bertram L (2011) Towards unveiling the genetics of neurodegenerative diseases. Semin Neurol 31, 531-541.

[15] Lanoiselée HM, Nicolas G, Wallon D, Rovelet-Lecrux A, Lacour M, Rousseau S, Richard AC, Pasquier F, Rollin-Sillaire A, Martinaud O, Quillard-Muraine M, de la Sayette V, Boutoleau-Bretonniere C, Etcharry-Bouyx F, Chauviré V, Sarazin M, le Ber I, Epelbaum S, Jonveaux T, Rouaud O, Ceccaldi M, Félician O, Godefroy O, Formaglio M, Croisile B, Auriacombe S, Chamard L, Vincent JL, Sauvée M, Marelli-Tosi C, Gabelle A, Ozsancak C, Pariente J, Paquet C, Hannequin D, Campion D, collaborators of the CNR-MAJ project (2017) APP, PSEN1, and PSEN2 mutations in early-onset Alzheimer disease: A genetic screening study of familial and sporadic cases. PLoS Med 14, e1002270.

[16] Jarmolowicz AI, Chen HY, Panegyres PK (2014) The patterns of inheritance in early-onset dementia: Alzheimer's disease and frontotemporal dementia. Am J Alzheimers Dis Other Demen 30, 299-306.
[17] Wallon D, Rousseau S, Rovelet-Lecrux A, QuillardMuraine M, Guyant-Maréchal L, Martinaud O, Pariente J, Puel M, Rollin-Sillaire A, Pasquier F, Le Ber I, Sarazin M, Croisile B, Boutoleau-Bretonnière C, Thomas-Antérion C, Paquet C, Moreaud O, Gabelle A, Sellal F, Sauvée M, Laquerrière A, Duyckaerts C, Delisle MB, Streichenberger N, Lannes B, Frebourg T, Hannequin D, Campion D, collaborators of GMAJ project (2012) The French series of autosomal dominant early onset Alzheimer's disease cases: Mutation spectrum and cerebrospinal fluid biomarkers. J Alzheimers Dis 30, 847-56.

[18] Guerreiro RJ, Lohmann E, Kinsella E, Brás JM, Luu N, Gurunlian N, Dursun B, Bilgic B, Santana I, Hanagasi H, Gurvit H, Gibbs JR, Oliveira C, Emre M, Singleton A (2012) Exome sequencing reveals an unexpected genetic cause of disease: NOTCH3 mutation in a Turkish family with Alzheimer's disease. Neurobiol Aging 33, 1008.e1723.

[19] Pottier C, Hannequin D, Coutant S, Rovelet-Lecrux A, Wallon D, Rousseau S, Legallic S, Paquet C, Bombois S, Pariente J, Thomas-Anterion C, Michon A, Croisile B, Etcharry-Bouyx F, Berr C, Dartigues JF, Amouyel P, Dauchel $\mathrm{H}$, Boutoleau-Bretonnière $\mathrm{C}$, Thauvin $\mathrm{C}$, Frebourg T, Lambert JC, Campion D, PHRC GMAJ Collaborators (2012) High frequency of potentially pathogenic SORL1 mutations in autosomal dominant early-onset Alzheimer disease. Mol Psychiatry 17, 875-879.

[20] Jiang T, Yu JT, Zhu XC, Tan L (2013) TREM2 in Alzheimer's disease. Mol Neurobiol 48, 180-185.

[21] Pottier C, Wallon D, Rousseau S, Rovelet-Lecrux A, Richard AC, Rollin-Sillaire A, Frebourg T, Campion D, Hannequin D (2013) TREM2 R47H variant as a risk factor for early-onset alzheimer's disease. J Alzheimers Dis 35, $45-49$.

[22] Slattery CF, Beck JA, Harper L, Adamson G, Abdi Z, Uphill J, Campbell T, Druyeh R, Mahoney CJ, Rohrer JD, Kenny J, Lowe J, Leung KK, Barnes J, Clegg SL, Blair M, Nicholas JM, Guerreiro RJ, Rowe JB, Ponto C, Zerr I, Kretzschmar H, Gambetti P, Crutch SJ, Warren JD, Rossor MN, Fox NC, Collinge J, Schott JM, Mead S (2014) R47H TREM2 variant increases risk of typical early-onset Alzheimer's disease but not of prion or frontotemporal dementia. Alzheimers Dement 10, 602-608.e4.

[23] Jonsson T, Stefansson H, Steinberg S, Jonsdottir I, Jonsson PV, Snaedal J, Bjornsson S, Huttenlocher J, Levey AI, Lah JJ, Rujescu D, Hampel H, Giegling I, Andreassen OA, Engedal K, Ulstein I, Djurovic S, Ibrahim-Verbaas C, Hofman A, Ikram MA, van Duijn CM, Thorsteinsdottir U, Kong A, Stefansson K (2013) Variant of TREM2 associated with the risk of Alzheimer's disease. $N$ Engl J Med 368, 107-116.

[24] Guerreiro R, Wojtas A, Bras J, Carrasquillo M, Rogaeva E, Majounie E, Cruchaga C, Sassi C, Kauwe JS, Younkin S, Hazrati L, Collinge J, Pocock J, Lashley T, Williams J, Lambert JC, Amouyel P, Goate A, Rademakers R, Morgan K, Powell J, St George-Hyslop P, Singleton A, Hardy J, Alzheimer Genetic Analysis Group (2013) TREM2 variants in Alzheimer's disease. N Engl J Med 368, 117-127.

[25] Sims R, van der Lee SJ, Naj AC, Bellenguez C, Badarinarayan N, Jakobsdottir J, Kunkle BW, Boland A, Raybould R, Bis JC, Martin ER, Grenier-Boley B, Heilmann-Heimbach S, Chouraki V, Kuzma AB, Sleegers K, Vronskaya M, Ruiz A, Graham RR, Olaso R, Hoffmann P, Grove ML, Vardarajan BN, Hiltunen M, Nöthen MM, White CC, Hamilton-Nelson KL, Epelbaum J, Maier 
W, Choi SH, Beecham GW, Dulary C, Herms S, Smith AV, Funk CC, Derbois C, Forstner AJ, Ahmad S, Li H, Bacq D, Harold D, Satizabal CL, Valladares O, Squassina A, Thomas R, Brody JA, Qu L, Sánchez-Juan P, Morgan T, Wolters FJ, Zhao Y, Garcia FS, Denning N, Fornage M, Malamon J, Naranjo MCD, Majounie E, Mosley TH, Dombroski B, Wallon D, Lupton MK, Dupuis J, Whitehead P, Fratiglioni L, Medway C, Jian X, Mukherjee S, Keller L, Brown K, Lin H, Cantwell LB, Panza F, McGuinness B, Moreno-Grau S, Burgess JD, Solfrizzi V, Proitsi P, Adams HH, Allen M, Seripa D, Pastor P, Cupples LA, Price ND, Hannequin D, Frank-García A, Levy D, Chakrabarty P, Caffarra P, Giegling I, Beiser AS, Giedraitis V, Hampel H, Garcia ME, Wang X, Lannfelt L, Mecocci P, Eiriksdottir G, Crane PK, Pasquier F, Boccardi V, Henández I, Barber RC, Scherer M, Tarraga L, Adams PM, Leber M, Chen Y, Albert MS, Riedel-Heller S, Emilsson V, Beekly D, Braae A, Schmidt R, Blacker D, Masullo C, Schmidt H, Doody RS, Spalletta Jr G, WTL, Fairchild TJ, Bossú P, Lopez OL, Frosch MP, Sacchinelli E, Ghetti B, Yang Q, Huebinger RM, Jessen F, Li S, Kamboh MI, Morris J, Sotolongo-Grau O, Katz MJ, Corcoran C, Dunstan M, Braddel A, Thomas C, Meggy A, Marshall R, Gerrish A, Chapman J, Aguilar M, Taylor S, Hill M, Fairén MD, Hodges A, Vellas B, Soininen H, Kloszewska I, Daniilidou M, Uphill J, Patel Y, Hughes JT, Lord J, Turton J, Hartmann AM, Cecchetti R, Fenoglio C, Serpente M, Arcaro M, Caltagirone C, Orfei MD, Ciaramella A, Pichler S, Mayhaus M, Gu W, Lleó A, Fortea J, Blesa R, Barber IS, Brookes K, Cupidi C, Maletta RG, Carrell D, Sorbi S, Moebus S, Urbano M, Pilotto A, Kornhuber J, Bosco P, Todd S, Craig D, Johnston J, Gill M, Lawlor B, Lynch A, Fox NC, Hardy J, ARUK Consortium, Albin RL, Apostolova LG, Arnold SE, Asthana S, Atwood CS, Baldwin CT, Barnes LL, Barral S, Beach TG, Becker JT, Bigio EH, Bird TD, Boeve BF, Bowen JD, Boxer A, Burke JR, Burns JM, Buxbaum JD, Cairns NJ, Cao C, Carlson CS, Carlsson CM, Carney RM, Carrasquillo MM, Carroll SL, Diaz CC, Chui HC, Clark DG, Cribbs DH, Crocco EA, DeCarli C, Dick M, Duara R, Evans DA, Faber KM, Fallon KB, Fardo DW, Farlow MR, Ferris S, Foroud TM, Galasko DR, Gearing M, Geschwind DH, Gilbert JR, Graff-Radford NR, Green RC, Growdon JH, Hamilton RL, Harrell LE, Honig LS, Huentelman MJ, Hulette CM, Hyman BT, Jarvik GP, Abner E, Jin LW, Jun G, Karydas A, Kaye JA, Kim R, Kowall NW, Kramer JH, LaFerla FM, Lah JJ, Leverenz JB, Levey AI, Li G, Lieberman AP, Lunetta KL, Lyketsos CG, Marson DC, Martiniuk F, Mash DC, Masliah E, McCormick WC, McCurry SM, McDavid AN, McKee AC, Mesulam M, Miller BL, Miller CA, Miller JW, Morris JC, Murrell JR, Myers AJ, O’Bryant S, Olichney JM, Pankratz VS, Parisi JE, Paulson HL, Perry W, Peskind E, Pierce A, Poon WW, Potter H, Quinn JF, Raj A, Raskind M, Reisberg B, Reitz C, Ringman JM, Roberson ED, Rogaeva E, Rosen HJ, Rosenberg RN, Sager MA, Saykin AJ, Schneider JA, Schneider LS, Seeley WW, Smith AG, Sonnen JA, Spina S, Stern RA, Swerdlow RH, Tanzi RE, Thornton-Wells TA, Trojanowski JQ, Troncoso JC, Van Deerlin VM, Van Eldik LJ, Vinters HV, Vonsattel JP, Weintraub S, Welsh-Bohmer KA, Wilhelmsen KC, Williamson J, Wingo TS, Woltjer RL, Wright CB, Yu CE, Yu L, Garzia F, Golamaully F, Septier G, Engelborghs S, Vandenberghe R, De Deyn PP, Fernadez CM, Benito YA, Thonberg H, Forsell C, Lilius L, Kinhult-Stählbom A, Kilander L, Brundin R, Concari L, Helisalmi S, Koivisto
AM, Haapasalo A, Dermecourt V, Fievet N, Hanon O, Dufouil C, Brice A, Ritchie K, Dubois B, Himali JJ, Keene CD, Tschanz J, Fitzpatrick AL, Kukull WA, Norton M, Aspelund T, Larson EB, Munger R, Rotter JI, Lipton RB, Bullido MJ, Hofman A, Montine TJ, Coto E, Boerwinkle E, Petersen RC, Alvarez V, Rivadeneira F, Reiman EM, Gallo M, O’Donnell CJ, Reisch JS, Bruni AC, Royall DR, Dichgans M, Sano M, Galimberti D, St George-Hyslop P, Scarpini E, Tsuang DW, Mancuso M, Bonuccelli U, Winslow AR, Daniele A, Wu CK, GERAD/PERADES, CHARGE, ADGC, EADI, Peters O, Nacmias B, Riemenschneider M, Heun R, Brayne C, Rubinsztein DC, Bras J, Guerreiro R, Al-Chalabi A, Shaw CE, Collinge J, Mann D, Tsolaki M, Clarimón J, Sussams R, Lovestone S, O'Donovan MC, Owen MJ, Behrens TW, Mead S, Goate AM, Uitterlinden AG, Holmes C, Cruchaga C, Ingelsson M, Bennett DA, Powell J, Golde TE, Graff C, De Jager PL, Morgan K, Ertekin-Taner N, Combarros O, Psaty BM, Passmore P, Younkin SG, Berr C, Gudnason V, Rujescu D, Dickson DW, Dartigues JF, DeStefano AL, OrtegaCubero S, Hakonarson H, Campion D, Boada M, Kauwe JK, Farrer LA, Van Broeckhoven C, Ikram MA, Jones L, Haines JL, Tzourio C, Launer LJ, Escott-Price V, Mayeux R, Deleuze JF, Amin N, Holmans PA, Pericak-Vance MA, Amouyel P, van Duijn CM, Ramirez A, Wang LS, Lambert JC, Seshadri S, Williams J, Schellenberg GD (2017) Rare coding variants in PLCG2, ABI3, and TREM2 implicate microglial-mediated innate immunity in Alzheimer's disease. Nat Genet 49, 1373-1384.

[26] Cacace R, Van den Bossche T, Engelborghs S, Geerts N, Laureys A, Dillen L, Graff C, Thonberg H, Chiang HH, Pastor P, Ortega-Cubero S, Pastor MA, Diehl-Schmid J, Alexopoulos P, Benussi L, Ghidoni R, Binetti G, Nacmias B, Sorbi S, Sanchez-Valle R, Lladó A, Gelpi E, Almeida MR, Santana I, Tsolaki M, Koutroumani M, Clarimon J, Lleó A, Fortea J, de Mendonça, Martins M, Borroni B, Padovani A, Matej R, Rohan Z, Vandenbulcke M, Vandenberghe R, De Deyn PP, Cras P, van der Zee J, Sleegers K, Van Broeckhoven C, Belgium Neurology (BELNEU) Consortium and the European Early-Onset Dementia (EU EOD) Consortium (2015) Rare variants in PLD3 do not affect risk for early-onset Alzheimer disease in a European Consortium Cohort. Hum Mutat 36, 1226-1235.

[27] Piccoli E, Rossi G, Rossi T, Pelliccioni G, D’Amato I, Tagliavini F, Di Fede G (2016) Novel PSEN1 mutations (H214N and R220P) associated with familial Alzheimer's disease identified by targeted exome sequencing. Neurobiol Aging 40, 192.e7-11.

[28] Farrer LA, Cupples LA, Haines JL, Hyman B, Kukull WA, Mayeux R, Myers RH, Pericak-Vance MA, Risch N, van Duijn CM (1997) Effects of age, sex, and ethnicity on the association between apolipoprotein E genotype and Alzheimer disease. A meta-analysis. APOE and Alzheimer Disease Meta Analysis Consortium. JAMA 278, 1349-1356.

[29] Harold D, Abraham R, Hollingworth P, Sims R, Gerrish A, Hamshere ML, Pahwa JS, Moskvina V, Dowzell K, Williams A, Jones N, Thomas C, Stretton A, Morgan AR, Lovestone S, Powell J, Proitsi P, Lupton MK, Brayne C, Rubinsztein DC, Gill M, Lawlor B, Lynch A, Morgan K, Brown KS, Passmore PA, Craig D, McGuinness B, Todd S, Holmes C, Mann D, Smith AD, Love S, Kehoe PG, Hardy J, Mead S, Fox N, Rossor M, Collinge J, Maier W, Jessen F, Schürmann B, Heun R, van den Bussche H, Heuser I, Kornhuber J, Wiltfang J, Dichgans M, Frölich L, Hampel 
H, Hüll M, Rujescu D, Goate AM, Kauwe JS, Cruchaga C, Nowotny P, Morris JC, Mayo K, Sleegers K, Bettens K, Engelborghs S, De Deyn PP, Van Broeckhoven C, Livingston G, Bass NJ, Gurling H, McQuillin A, Gwilliam R, Deloukas P, Al-Chalabi A, Shaw CE, Tsolaki M, Singleton $\mathrm{AB}$, Guerreiro R, Mühleisen TW, Nöthen MM, Moebus S, Jöckel KH, Klopp N, Wichmann HE, Carrasquillo MM, Pankratz VS, Younkin SG, Holmans PA, O’Donovan M, Owen MJ, Williams J (2009) Genome wide association study identifies variants at CLU and PICALM associated with Alzheimer's disease. Nat Genet 41, 1088-1093.

[30] Hollingworth P, Harold D, Sims R, Gerrish A, Lambert JC, Carrasquillo MM, Abraham R, Hamshere ML, Pahwa JS, Moskvina V, Dowzell K, Jones N, Stretton A, Thomas C, Richards A, Ivanov D, Widdowson C, Chapman J, Lovestone S, Powell J, Proitsi P, Lupton MK, Brayne C, Rubinsztein DC, Gill M, Lawlor B, Lynch A, Brown KS, Passmore PA, Craig D, McGuinness B, Todd S, Holmes C, Mann D, Smith AD, Beaumont H, Warden D, Wilcock G, Love S, Kehoe PG, Hooper NM, Vardy ER, Hardy J, Mead S, Fox NC, Rossor M, Collinge J, Maier W, Jessen F, Rüther E, Schürmann B, Heun R, Kölsch H, van den Bussche H, Heuser I, Kornhuber J, Wiltfang J, Dichgans M, Frölich L, Hampel H, Gallacher J, Hüll M, Rujescu D, Giegling I, Goate AM, Kauwe JS, Cruchaga C, Nowotny P, Morris JC, Mayo K, Sleegers K, Bettens K, Engelborghs S, De Deyn PP, Van Broeckhoven C, Livingston G, Bass NJ, Gurling H, McQuillin A, Gwilliam R, Deloukas P, Al-Chalabi A, Shaw CE, Tsolaki M, Singleton AB, Guerreiro R, Mühleisen TW, Nöthen MM, Moebus S, Jöckel KH, Klopp N, Wichmann HE, Pankratz VS, Sando SB, Aasly JO, Barcikowska M, Wszolek ZK, Dickson DW, Graff-Radford NR, Petersen RC, Alzheimer's Disease Neuroimaging Initiative, van Duijn CM, Breteler MM, Ikram MA, DeStefano AL, Fitzpatrick AL, Lopez O, Launer LJ, Seshadri S, CHARGE consortium, Berr C, Campion D, Epelbaum J, Dartigues JF, Tzourio C, Alpérovitch A, Lathrop M, EADI1 consortium, Feulner TM, Friedrich P, Riehle C, Krawczak M, Schreiber S, Mayhaus M, Nicolhaus S, Wagenpfeil S, Steinberg S, Stefansson H, Stefansson K, Snaedal J, Björnsson S, Jonsson PV, Chouraki V, Genier-Boley B, Hiltunen M, Soininen H, Combarros O, Zelenika D, Delepine M, Bullido MJ, Pasquier F, Mateo I, FrankGarcia A, Porcellini E, Hanon O, Coto E, Alvarez V, Bosco P, Siciliano G, Mancuso M, Panza F, Solfrizzi V, Nacmias B, Sorbi S, Bossú P, Piccardi P, Arosio B, Annoni G, Seripa D, Pilotto A, Scarpini E, Galimberti D, Brice A, Hannequin D, Licastro F, Jones L, Holmans PA, Jonsson T, Riemenschneider M, Morgan K, Younkin SG, Owen MJ, O'Donovan M, Amouyel P, Williams J (2011) Common variants at ABCA7, MS4A6A/MS4A4E, EPHA1, CD33, and CD2AP are associated with Alzheimer's disease. Nat Genet 43, 429-435.

[31] Lupton MK, Proitsi P, Danillidou M, Tsolaki M, Hamilton G, Wroe R, Pritchard M, Lord K, Martin BM, Kloszewska I, Soininen H, Mecocci P, Vellas B, Harold D, Hollingworth P, Lovestone S, Powell JF (2011) Deep sequencing of the Nicastrin gene in pooled DNA, the identification of genetic variants that affect risk of Alzheimer's disease. PLoS One 6, e17298.

[32] Kohli MA, Cukier HN, Hamilton-Nelson KL, Rolati S, Kunkle BW, Whitehead PL, Züchner SL, Farrer LA, Martin ER, Beecham GW, Haines JL, Vance JM, Cuccaro ML, Gilbert JR, Schellenberg GD, Carney RM, Pericak-
Vance MA (2016) Segregation of a rare TTC3 variant in an extended family with late-onset Alzheimer disease. Neurol Genet 2, e41.

[33] Ratnavalli E, Brayne C, Dawson K, Hodges JR (2002) The prevalence of frontotemporal dementia. Neurology $\mathbf{5 8}$, 1615-1621.

[34] Bird T, Knopman D, VanSwieten J, Rosso S, Feldman H, Tanabe H, Graff-Radford N, Geschwind D, Verpillat P, Hutton M (2003) Epidemiology and genetics of frontotemporal dementia/Pick's disease. Ann Neurol 54, S29-S31.

[35] Goldman JS, Farmer JS, Wood EM, Johnson JK, Boxer A, Neuhaus J, Lomen-Hoerth C, Wilhelmsen KC, Lee VM, Grossman M, Miller BL (2005) Comparison of family histories in FTLD subtypes and related tauopathies. Neurology 65, 1817-1819.

[36] Pickering-Brown SM (2007) The complex aetiology of frontotemporal lobar degeneration. Exp Neurol 114, 39-47.

[37] Lynch T, Sano M, Marder KS, Bell KL, Foster NL, Defendini RF, Sima AA, Keohane C, Nygaard TG, Fahn S, et al. (1994) Clinical characteristics of a family with chromosome 17-linked disinhibition-dementia-parkinsonismamyotrophy complex. Neurology 44, 1878-1884.

[38] Hutton M, Lendon CL, Rizzu P, Baker M, Froelich S, Houlden H, Pickering-Brown S, Chakraverty S, Isaacs A, Grover A, Hackett J, Adamson J, Lincoln S, Dickson D, Davies P, Petersen RC, Stevens M, de Graaff E, Wauters E, van Baren J, Hillebrand M, Joosse M, Kwon JM, Nowotny P, Che LK, Norton J, Morris JC, Reed LA, Trojanowski J, Basun H, Lannfelt L, Neystat M, Fahn S, Dark F, Tannenberg T, Dodd PR, Hayward N, Kwok JB, Schofield PR, Andreadis A, Snowden J, Craufurd D, Neary D, Owen F, Oostr, BA, Hardy J, Goate A, van Swieten J, Mann D, Lynch T, Heutink P (1998) Association of missense and $5^{\prime}$-splice-site mutations in tau with the inherited dementia FTDP-17. Nature 393, 702-705.

[39] Wang Y, Mandelkow E (2015) Tau in physiology and pathology. Nat Rev Neurosci 17, 22-35.

[40] Neve RL, Harris P, Kosik K, Kurnit DM, Donlon TA (1986) Identification of cDNA clones for the human microtubule associated protein tau and chromosomal localization of the genes for tau and microtubule-associated protein 2. Brain Res 387, 271-280.

[41] Ghetti B, Oblak AL, Boeve BF, Johnson KA, Dickerson BC, Goedert M (2015) Invited review: Frontotemporal dementia caused by microtubule-associated protein tau gene (MAPT) mutations: A chameleon for neuropathology and neuroimaging. Neuropathol Appl Neurobiol 41, 24-46.

[42] Rademakers R, Cruts M, van Broeckhoven C (2004) The role of tau (MAPT) in frontotemporal dementia and related tauopathies. Hum Mutat 24, 277-295.

[43] Malkani R, D’Souza I, Gwinn-Hardy K, Schellenberg GD, Hardy J, Momeni P (2006) A MAPT mutation in a regulatory element upstream of exon 10 causes frontotemporal dementia. Neurobiol Dis 22, 401-403.

[44] Hong M, Zhukareva V, Vogelsberg-Ragaglia V, Wszolek Z, Reed L, Miller BI, Geschwind DH, Bird TD, McKeel D, Goate A, Morris JC, Wilhelmsen KC, Schellenberg GD, Trojanowski JQ, Lee VM (1998) Mutation-specific functional impairments in distinct Tau isoforms of hereditary FTDP-17. Science 282, 1914-1917.

[45] Goedert M, Jakes R, Crowther RA (1999) Effects of frontotemporal dementia FTDP-17 mutations on heparin- 
induced assembly of tau filaments. FEBS Lett 450, 306-311.

[46] Rovelet-Lecrux A, Lecourtois M, Thomas-Anterion C, Le Ber I, Brice A, Frebourg T, Hannequin D, Campion D (2009) Partial deletion of the MAPT gene: A novel mechanism of FTDP-17. Hum Mutat 30, 591-602.

[47] Rovelet-Lecrux A, Hannequin D, Guillin O, Legallic S, Jurici S, Wallon D, Frebourg T, Campion D (2010) Frontotemporal dementia phenotype associated with MAPT gene duplication. J Alzheimers Dis 21, 897-902.

[48] Mann DMA, Snowden JS (2017) Frontotemporal lobar degeneration: Pathogenesis, pathology and pathways to phenotype. Brain Pathol 27, 723-736.

[49] Baker M, Mackenzie IR, Pickering-Brown SM, Gass J, Rademakers R, Lindholm C, Snowden J, Adamson J, Sadovnick AD, Rollinson S, Cannon A, Dwosh E, Neary D, Melquist S, Richardson A, Dickson D, Berger Z, Eriksen J, Robinson T, Zehr C, Dickey CA, Crook R, McGowan E, Mann D, Boeve B, Feldman H, Hutton M (2006) Mutations in progranulin cause tau-negative frontotemporal dementia linked to chromosome 17. Nature 442, 916-919.

[50] Cruts M, Gijselinck I, van der Zee J, Engelborghs S, Wils H, Pirici D, Rademakers R, Vandenberghe R, Dermaut B, Martin JJ, van Duijn C, Peeters K, Sciot R, Santens P, De Pooter T, Mattheijssens M, Van den Broeck M, Cuijt I, Vennekens K, De Deyn PP, Kumar-Singh S, Van Broeckhoven C (2006) Null mutations in progranulin cause ubiquitin-positive frontotemporal dementia linked to chromosome 17q21. Nature 442, 920-924.

[51] Rademakers R, Neumann M, Mackenzie IR (2012) Advances in understanding the molecular basis of frontotemporal dementia. Nat Rev Neurol 8, 423-434.

[52] Petkau TL, Leavitt BR (2014) Progranulin in neurodegenerative disease. Trends Neurosci 37, 388-398.

[53] Gass J, Cannon A, Mackenzie IR, Boeve B, Baker M, Adamson J, Crook R, Melquist S, Kuntz K, Petersen R, Josephs K, Pickering-Brown SM, Graff-Radford N, Uitti R, Dickson D, Wszolek Z, Gonzalez J, Beach TG, Bigio E, Johnson N, Weintraub S, Mesulam M, White 3rd CL, Woodruff B, Caselli R, Hsiung GY, Feldman H, Knopman D, Hutton M, Rademakers R (2006) Mutations in progranulin are a major cause of ubiquitin-positive frontotemporal lobar degeneration. Hum Mol Genet 15, 2988-3001.

[54] Yu CE, Bird TD, Bekris LM, Montine TJ, Leverenz JB, Steinbart E, Galloway NM, Feldman H, Woltjer R, Miller CA, Wood EM, Grossman M, McCluskey L, Clark CM, Neumann M, Danek A, Galasko DR, Arnold SE, ChenPlotkin A, Karydas A, Miller BL, Trojanowski JQ, Lee VM, Schellenberg GD, Van Deerlin VM (2010) The spectrum of mutations in progranulin: A collaborative study screening 545 cases of neurodegeneration. Arch Neurol 67, 161-170.

[55] Neumann M, Sampathu DM, Kwong LK, Truax AC, Micsenyi MC, Chou TT, Bruce J, Schuck T, Grossman M, Clark CM, McCluskey LF, Miller BL, Masliah E, Mackenzie IR, Feldman H, Feiden W, Kretzschmar HA, Trojanowski JQ, Lee VM (2006) Ubiquitinated TDP-43 in frontotemporal lobar degeneration and amyotrophic lateral sclerosis. Science 314, 130-133.

[56] Mackenzie IR, Neumann M, Baborie A, Sampathu DM, Du Plessis D, Jaros E, Perry RH, Trojanowski JQ, Mann DM, Lee VM (2011) A harmonized classification system for FTLD-TDP pathology. Acta Neuropathol 122, 111-113.
[57] Benussi A, Padovani A, Borroni B (2015) Phenotypic heterogeneity of monogenic frontotemporal dementia. Front Aging Neurosci 7, 171.

[58] Le Ber I, Camuzat A, Hannequin D, Pasquier F, Guedj E, Rovelet-Lecrux A, Hahn-Barma V, van der Zee J, Clot F, Bakchine S, Puel M, Ghanim M, Lacomblez L, Mikol J, Deramecourt V, Lejeune P, de la Sayette V, Belliard S, Vercelletto M, Meyrignac C, Van Broeckhoven C, Lambert JC, Verpillat P, Campion D, Habert MO, Dubois B, Brice A, French research network on FTD/FTD-MND (2008) Phenotype variability in progranulin mutation carriers: A clinical, neuropsychological, imaging and genetic study. Brain 131, 732-746.

[59] Rainero I, Rubino E, Negro E, Gallone S, Galimberti D, Gentile S, Scarpini E, Pinessi L (2011) Heterosexual pedophilia in a frontotemporal dementia patient with a mutation in the progranulin gene. Biol Psychiatry 70, 43-44.

[60] Cerami C, Marcone A, Galimberti D, Villa C, Scarpini E, Cappa SF (2011) From genotype to phenotype: Two cases of genetic frontotemporal lobar degeneration with premorbid bipolar disorder. J Alzheimers Dis 27, 791-797.

[61] Pietroboni AM, Fumagalli GG, Ghezzi L, Fenoglio C, Cortini F, Serpente M, Cantoni C, Rotondo E, Corti P, Carecchio M, Bassi M, Bresolin N, Galbiati D, Galimberti D, Scarpini E (2011) Phenotypic heterogeneity of the GRN Asp22fs mutation in a large Italian kindred. J Alzheimers Dis 24, 253-259.

[62] Bruni AC, Momeni P, Bernardi L, Tomaino C, Frangipane F, Elder J, Kawarai T, Sato C, Pradella S, Wakutani Y, Anfossi M, Gallo M, Geracitano S, Costanzo A, Smirne N, Curcio SA, Mirabelli M, Puccio G, Colao R, Maletta RG, Kertesz A, St George-Hyslop P, Hardy J, Rogaeva E (2007) Heterogeneity within a large kindred with frontotemporal dementia: A novel progranulin mutation. Neurology 69, 140-147.

[63] Ghidoni R, Benussi L, Glionna M, Franzoni M, Binetti G (2008) Low plasma progranulin levels predict progranulin mutations in frontotemporal lobar degeneration. Neurology 71, 1235-1239.

[64] Carecchio M, Fenoglio C, De Riz M, Guidi I, Comi C, Cortini F, Venturelli E, Restelli I, Cantoni C, Bresolin N, Monaco F, Scarpini E, Galimberti D (2009) Progranulin plasma levels as potential biomarker for the identification of GRN deletion carriers. A case with atypical onset as clinical amnestic Mild Cognitive Impairment converted to Alzheimer's disease. J Neurol Sci 287, 291-293.

[65] Pickford F, Marcus J, Camargo LM, Xiao Q, Graham D, Mo JR, Burkhardt M, Kulkarni V, Crispino J, Hering H, Hutton M (2011) Progranulin is a chemoattractant for microglia and stimulates their endocytic activity. Am J Pathol 178, 284-295.

[66] Tang W, Lu Y, Tian QY, Zhang Y, Guo FJ, Liu GY, Syed NM, Lai Y, Lin EA, Kong L, Su J, Yin F, Ding AH, Zanin-Zhorov A, Dustin ML, Tao J, Craft J, Yin Z, Feng JQ, Abramson SB, Yu XP, Liu CJ (2011) The growth factor progranulin binds to TNF receptors and is therapeutic against inflammatory arthritis in mice. Science 332, 478-484.

[67] Galimberti D, Bonsi R, Fenoglio C, Serpente M, Cioffi SM, Fumagalli G, Arighi A, Ghezzi L, Arcaro M, Mercurio M, Rotondo E, Scarpini E (2015) Inflammatory molecules in Frontotemporal Dementia: Cerebrospinal fluid signature of progranulin mutation carriers. Brain Behav Immun 49, 182-187. 
[68] Hosler BA, Siddique T, Sapp PC, Sailor W, Huang MC, Hossain A, Daube JR, Nance M, Fan C, Kaplan J, Hung WY, McKenna-Yasek D, Haines JL, Pericak-Vance MA, Horvitz HR, Brown Jr RH (2000) Linkage of familial amyotrophic lateral sclerosis with frontotemporal dementia to chromosome 9q21-q22. JAMA 284, 1664-1669.

[69] Morita M, Al-Chalabi A, Andersen PM, Hosler B, Sapp P, Englund E, Mitchell JE, Habgood JJ, de Belleroche J, Xi J, Jongjaroenprasert W, Horvitz HR, Gunnarsson LG, Brown Jr RH (2006) A locus on chromosome 9p confers susceptibility to ALS and frontotemporal dementia. Neurology 66, 839-844.

[70] DeJesus-Hernandez M, Mackenzie IR, Boeve BF, Boxer AL, Baker M, Rutherford NJ, Nicholson AM, Finch NA, Flynn H, Adamson J, Kouri N, Wojtas A, Sengdy P, Hsiung GY, Karydas A, Seeley WW, Josephs KA, Coppola G, Geschwind DH, Wszolek ZK, Feldman H, Knopman DS, Petersen RC, Miller BL, Dickson DW, Boylan KB, GraffRadford NR, Rademakers R (2011) Expanded GGGGCC hexanucleotide repeat in noncoding region of C9ORF72 causes chromosome 9p-linked FTD and ALS. Neuron 72, 245-256.

[71] Renton AE, Majounie E, Waite A, Simón-Sánchez J, Rollinson S, Gibbs JR, Schymick JC, Laaksovirta H, van Swieten JC, Myllykangas L, Kalimo H, Paetau A, Abramzon Y, Remes AM, Kaganovich A, Scholz SW, Duckworth J, Ding J, Harmer DW, Hernandez DG, Johnson JO, Mok K, Ryten M, Trabzuni D, Guerreiro RJ, Orrell RW, Neal J, Murray A, Pearson J, Jansen IE, Sondervan D, Seelaar H, Blake D, Young K, Halliwell N, Callister JB, Toulson G, Richardson A, Gerhard A, Snowden J, Mann D, Neary D, Nalls MA, Peuralinna T, Jansson L, Isoviita VM, Kaivorinne AL, Hölttä-Vuori M, Ikonen E, Sulkava R, Benatar M, Wuu J, Chiò A, Restagno G, Borghero G, Sabatelli M, ITALSGEN Consortium, Heckerman D, Rogaeva E, Zinman L, Rothstein JD, Sendtner M, Drepper C, Eichler EE, Alkan C, Abdullaev Z, Pack SD, Dutra A, Pak E, Hardy J, Singleton A, Williams NM, Heutink P, Pickering-Brown S, Morris HR, Tienari PJ, Traynor BJ (2011). A hexanucleotide repeat expansion in C9ORF72 is the cause of chromosome 9p21-linked ALS-FTD. Neuron 72, 257-268.

[72] van Blitterswijk M, DeJesus-Hernandez M, Niemantsverdriet E, Murray ME, Heckman MG, Diehl NN, Brown PH, Baker MC, Finch NA, Bauer PO, Serrano G, Beach TG, Josephs KA, Knopman DS, Petersen RC, Boeve BF, Graff-Radford NR, Boylan KB, Petrucelli L, Dickson DW, Rademakers R (2013) Association between repeat sizes and clinical and pathological characteristics in carriers of C9ORF72 repeat expansions (Xpansize72): A cross-sectional cohort study. Lancet Neurol 12, 978-988.

[73] Ishiura H, Tsuji S (2015) Epidemiology and molecular mechanism of frontotemporal lobar degeneration/amyotrophic lateral sclerosis with repeat expansion mutation in C9orf72. J Neurogenet 29, 85-94.

[74] Rohrer JD, Isaacs AM, Mizielinska S, Mead S, Lashley T, Wray S, Sidle K, Fratta P, Orrell RW, Hardy J, Holton J, Revesz T, Rossor MN, Warren JD (2015) C9orf72 expansions in frontotemporal dementia and amyotrophic lateral sclerosis. Lancet Neurol 14, 291-301.

[75] Cooper-Knock J, Kirby J, Highley R, Shaw PJ (2015) The spectrum of C9orf72-mediated neurodegeneration and amyotrophic lateral sclerosis. Neurotherapeutics 12, 326-339.
[76] Snowden JS, Rollinson S, Thompson JC, Harris JM, Stopford CL, Richardson AM, Jones M, Gerhard A, Davidson YS, Robinson A, Gibbons L, Hu Q, DuPlessis D, Neary D, Mann DM, Pickering-Brown SM (2012) Distinct clinical and pathological characteristics of frontotemporal dementia associated with C9ORF72 mutations. Brain 135, 693-708.

[77] Galimberti D, Fenoglio C, Serpente M, Villa C, Bonsi R, Arighi A, Fumagalli GG, Del Bo R, Bruni AC, Anfossi M, Clodomiro A, Cupidi C, Nacmias B, Sorbi S, Piaceri I, Bagnoli S, Bessi V, Marcone A, Cerami C, Cappa SF, Filippi M, Agosta F, Magnani G, Comi G, Franceschi M, Rainero I, Giordana MT, Rubino E, Ferrero P, Rogaeva E, Xi Z, Confaloni A, Piscopo P, Bruno G, Talarico G, Cagnin A, Clerici F, Dell'Osso B, Comi GP, Altamura AC, Mariani C, Scarpini E (2013) Autosomal dominant Frontotemporal Lobar Degeneration due to the C9ORF72 hexanucleotide repeat expansion: Lateonset psychotic clinical presentation. Biol Psychiatry 74, 384-391.

[78] Galimberti D, Reif A, Dell'osso B, Kittel-Schneider S, Leonhard C, Herr A, Palazzo C, Villa C, Fenoglio C, Serpente M, Cioffi SM, Prunas C, Paoli RA, Altamura AC, Scarpini (2014) C9ORF72 hexanucleotide repeat expansion is a rare cause of schizophrenia. Neurobiol Aging 35, 1214 e1217-1214 e1210.

[79] Galimberti D, Reif A, Dell'Osso B, Palazzo C, Villa C, Fenoglio C, Kittel-Schneider S, Leonhard C, Olmes DG, Serpente M, Paoli RA, Altamura AC, Scarpini E (2014) C9ORF72 hexanucleotide repeat expansion as a rare cause of bipolar disorder. Bipolar Disord 16, 448-449.

[80] Majounie E, Abramzon Y, Renton AE, Perry R, Bassett SS, Pletnikova O, Troncoso JC, Hardy J, Singleton AB, Traynor BJ (2012) Repeat expansion in C9ORF72 in Alzheimer's disease. N Engl J Med 366, 283-284.

[81] Xi Z, Zinman L, Grinberg Y, Moreno D, Sato C, Bilbao JM, Ghani M, Hernández I, Ruiz A, Boada M, Morón FJ, Lang AE, Marras C, Bruni A, Colao R, Maletta RG, Puccio G, Rainero I, Pinessi L, Galimberti D, Morrison KE, Moorby C, Stockton JD, Masellis M, Black SE, Hazrati LN, Liang Y, van Haersma de With J, Fornazzari L, Villagra R, RojasGarcia R, Clarimón J, Mayeux R, Robertson J, St GeorgeHyslop P, Rogaeva E (2012) Investigation of c9orf72 in 4 neurodegenerative disorders. Arch Neurol 69, 1583-1590.

[82] Mori K, Arzberger T, Grässer FA, Gijselinck I, May S, Rentzsch K, Weng SM, Schludi MH, van der Zee J, Cruts M, Van Broeckhoven C, Kremmer E, Kretzschmar HA, Haass C, Edbauer D (2013) Bidirectional transcripts of the expanded $\mathrm{C} 9$ orf 72 hexanucleotide repeat are translated into aggregating dipeptide repeat proteins. Acta Neuropathol 126, 881-893.

[83] Haeusler AR, Donnelly CJ, Rothstein JD (2016) The expanding biology of the C9orf72 nucleotide repeat expansion in neurodegenerative disease. Nat Rev Neurosci 17, 383-395.

[84] Reddy K, Zamiri B, Stanley SY, Macgregor RB, Pearson CE (2013) The disease-associated r(GGGGCC)n repeat from the C9ORF72 gene forms tract length-dependent uniand multi-molecular RNA G-quadruplex structures. J Biol Chem 88, 9860-9866.

[85] Mizielinska S, Isaacs AM (2014) C9orf72 amyotrophic lateral sclerosis and frontotemporal dementia: Gain or loss of function? Curr Opin Neurol 27, 515-523.

[86] Gijselinck I, Van Mossevelde S, van der Zee J, Sieben A, Engelborghs S, De Bleecker J, Ivanoiu A, Deryck O, 
Edbauer D, Zhang M, Heeman B, Bäumer V Van den Broeck M, Mattheijssens M, Peeters K, Rogaeva E, De Jonghe P, Cras P, Martin JJ, de Deyn PP, Cruts M, Van Broeckhoven C (2016) The C9orf72 repeat size correlates with onset age of disease, DNA methylation and transcriptional downregulation of the promoter. Mol Psychiatry 21, 1112-1124.

[87] May S, Hornburg D, Schludi MH, Arzberger T, Rentzsch K, Schwenk BM, Grässer FA, Mori K, Kremmer E, Banzhaf-Strathmann J, Mann M, Meissner F, Edbauer D (2014) C9orf72 FTLD/ALS associated Gly-Ala dipeptide repeat proteins cause neuronal toxicity and Unc119 sequestration. Acta Neuropathol 128, 485-503.

[88] van Blitterswijk M, Rademakers $R$ (2015) Neurodegenerative disease: $\mathrm{C} 9$ orf72 repeats compromise nucleocytoplasmic transport. Nat Rev Neurol 11, 670-672.

[89] Lehmer C, Oeckl P, Weishaupt JH, Volk AE, DiehlSchmid J, Schroeter ML, Lauer M, Kornhuber J, Levin J, Fassbender K, Landwehrmeyer B, German Consortium for Frontotemporal Lobar Degeneration, Schludi MH, Arzberger T, Kremmer E, Flatley A, Feederle R, Steinacker P, Weydt P, Ludolph AC, Edbauer D, Otto M (2017) Poly-GP in cerebrospinal fluid links C9orf72-associated dipeptide repeat expression to the asymptomatic phase of ALS/FTD. EMBO Mol Med 9, 859-868.

[90] Skibinski G, Parkinson NJ, Brown JM, Chakrabarti L, Lloyd SL, Hummerich H, Nielsen JE, Hodges JR, Spillantini MG, Thusgaard T, Brandner S, Brun A, Rossor MN, Gade A, Johannsen P, Sørensen SA, Gydesen S, Fisher EM, Collinge J (2005) Mutations in the endosomal ESCRTIII-complex subunit CHMP2B in frontotemporal dementia. Nat Genet 37, 806-808.

[91] Urwin H, Ghazi-Noori S, Collinge J, Isaacs A (2009) The role of CHMP2B in frontotemporal dementia. Biochem Soc Trans 37, 208-212.

[92] Lindquist SG, Braedgaard H, Svenstrup K, Isaacs AM, Nielsen JE, FReJA Consortium (2008) Frontotemporal dementia linked to chromosome 3 (FTD-3)-current concepts and the detection of a previously unknown branch of the Danish FTD-3 family. Eur J Neurol 15, 667-670.

[93] Urwin H, Authier A, Nielsen JE, Metcalf D, Powell C, Froud K, Malcolm DS, Holm I, Johannsen P, Brown J, Fisher EM, van der Zee J, Bruyland M, FReJA Consortium, Van Broeckhoven C, Collinge J, Brandner S, Futter C, Isaacs AM (2010) Disruption of endocytic trafficking in frontotemporal dementia with CHMP2B mutations. Hum Mol Genet 19, 2228-2238.

[94] Isaacs AM, Johannsen P, Holm I, Nielsen JE, FReJA consortium (2011) Frontotemporal dementia caused by CHMP2B mutations. Curr Alzheimer Res 8, 246-251.

[95] Watts GD, J Wymer J, Kovach MJ, Mehta SG, Mumm S, Darvish D, Pestronk A, Whyte MP, Kimonis VE (2004) Inclusion body myopathy associated with Paget disease of bone and frontotemporal dementia is caused by mutant valosincontaining protein. Nat Genet 36, 377-381.

[96] Spina S, Van Laar AD, Murrell JR, Hamilton RL, Kofler JK, Epperson F, Farlow MR, Lopez OL, Quinlan J, DeKosky ST, Ghetti B (2013) Phenotypic variability in three families with valosin-containing protein mutation. Eur J Neurol 20, 251-258.

[97] Ju J-S, Weihl CC (2010) Inclusion body myopathy, Paget's disease of the bone and fronto-temporal dementia: A disorder of autophagy. Hum Mol Genet 19, R38-R45.
[98] Ng ASL, Rademakers R, Miller BL (2015) Frontotemporal dementia: A bridge between dementia and neuromuscular disease. Ann N Y Acad Sci 1338, 71-93.

[99] Rea SL, Majcher V, Searle MS, Layfield R (2014) SQSTM1 mutations-bridging Paget disease of bone and ALS/FTLD. Exp Cell Res 325, 27-37.

[100] van der Zee J, Van Langenhove T, Kovacs GG, Dillen L, Deschamps W, Engelborghs S, Matěj R, Vandenbulcke M, Sieben A, Dermaut B, Smets K, Van Damme P, Merlin C, Laureys A, Van Den Broeck M, Mattheijssens M, Peeters K, Benussi L, Binetti G, Ghidoni R, Borroni B, Padovani A, Archetti S, Pastor P, Razquin C, OrtegaCubero S, Hernández I, Boada M, Ruiz A, de Mendonça A, Miltenberger-Miltényi G, do Couto FS, Sorbi S, Nacmias B, Bagnoli S, Graff C, Chiang HH, Thonberg H, Perneczky R, Diehl-Schmid J, Alexopoulos P, Frisoni GB, Bonvicini C, Synofzik M, Maetzler W, vom Hagen JM, Schöls L, Haack TB, Strom TM, Prokisch H, Dols-Icardo O, Clarimón J, Lleó A, Santana I, Almeida MR, Santiago B, Heneka MT, Jessen F, Ramirez A, Sanchez-Valle R, Llado A, Gelpi E, Sarafov S, Tournev I, Jordanova A, Parobkova E, Fabrizi GM, Testi S, Salmon E, Ströbel T, Santens P, Robberecht W, De Jonghe P, Martin JJ, Cras P, Vandenberghe R, De Deyn PP, Cruts M, Sleegers K, Van Broeckhoven C (2014) Rare mutations in SQSTM1 modify susceptibility to frontotemporal lobar degeneration. Acta Neuropathol 128, 397-410.

[101] Bannwarth S, Ait-El-Mkadem S, Chaussenot A, Genin EC, Lacas-Gervais S, Fragaki K, Berg-Alonso L, Kageyama Y, Serre V, Moore DG, Verschueren A, Rouzier C, Le Ber I, Augé G, Cochaud C, Lespinasse F, N'Guyen K, de Septenville A, Brice A, Yu-Wai-Man P, Sesaki H, Pouget J, Paquis-Flucklinger V (2014) A mitochondrial origin for frontotemporal dementia and amyotrophic lateral sclerosis through CHCHD10 involvement. Brain 137, 2329-2345.

[102] Zhang M, Xi Z, Zinman L, Bruni AC, Maletta RG, Curcio SA, Rainero I, Rubino E, Pinessi L, Nacmias B, Sorbi S, Galimberti D, Lang AE, Fox S, Surace EI, Ghani M, Guo J, Sato C, Moreno D, Liang Y, Keith J, Traynor BJ, St George-Hyslop P, Rogaeva E (2015) Mutation analysis of CHCHD10 in different neurodegenerative diseases. Brain 138(Pt 9), e380.

[103] Perrone F, Nguyen HP, Van Mossevelde S, Moisse M, Sieben A, Santens P, De Bleecker J, Vandenbulcke M, Engelborghs S, Baets J, Cras P, Vandenberghe R, De Jonghe P, De Deyn PP, Martin JJ, Van Damme P, Van Broeckhoven C, van der Zee J, Belgian Neurology consortium (2017) Investigating the role of ALS genes CHCHD10 and TUBA4A in Belgian FTD-ALS spectrum patients. Neurobiol Aging 51, 177.e9-177.

[104] Cirulli ET, Lasseigne BN, Petrovski S, Sapp PC, Dion PA, Leblond CS, Couthouis J, Lu YF, Wang Q, Krueger BJ, Ren Z, Keebler J, Han Y, Levy SE, Boone BE, Wimbish JR, Waite LL, Jones AL, Carulli JP, Day-Williams AG, Staropoli JF, Xin WW, Chesi A, Raphael AR, McKennaYasek D, Cady J, Vianney de Jong JM, Kenna KP, Smith BN, Topp S, Miller J, Gkazi A, FALS Sequencing Consortium, Al-Chalabi A, van den Berg LH, Veldink J, Silani V, Ticozzi N, Shaw CE, Baloh RH, Appel S, Simpson E, Lagier-Tourenne C, Pulst SM, Gibson S, Trojanowski JQ, Elman L, McCluskey L, Grossman M, Shneider NA, Chung WK, Ravits JM, Glass JD, Sims KB, Van Deerlin VM, Maniatis T, Hayes SD, Ordureau A, Swarup S, Landers J, Baas F, Allen AS, Bedlack RS, Harper JW, Gitler 
AD, Rouleau GA, Brown R, Harms MB, Cooper GM, Harris T, Myers RM, Goldstein DB (2015) Exome sequencing in amyotrophic lateral sclerosis identifies risk genes and pathways. Science 347, 1436-1441.

[105] Pottier C, Bieniek KF, Finch N, van de Vorst M, Baker M, Perkersen R, Brown P, Ravenscroft T, van Blitterswijk M, Nicholson AM, DeTure M, Knopman DS, Josephs KA, Parisi JE, Petersen RC, Boylan KB, Boeve BF, Graff-Radford NR, Veltman JA, Gilissen C, Murray ME, Dickson DW, Rademakers R (2015) Whole-genome sequencing reveals important role for TBK1 and OPTN mutations in frontotemporal lobar degeneration without motor neuron disease. Acta Neuropathol 130, 77-92.

[106] Rainero I, Rubino E, Michelerio A, D’Agata F, Gentile S, Pinessi L (2017) Recent advances in the molecular genetics of frontotemporal lobar degeneration. Funct Neurol 32, 7-16.

[107] Neumann M, Valori CF, Ansorge O, Kretzschmar HA, Munoz DG, Kusaka H, Yokota O, Ishihara K, Ang LC, Bilbao JM, Mackenzie IR (2012) Transportin 1 accumulates specifically with FET proteins but no other transportin cargos in FTLD-FUS and is absent in FUS inclusions in ALS with FUS mutations. Acta Neuropathol 124, 705-716.

[108] Dillen L, Van Langenhove T, Engelborghs S, Vandenbulcke M, Sarafov S, Tournev I, Merlin C, Cras P, Vandenberghe R, De Deyn PP, Jordanova A, Cruts M, Van Broeckhoven C, van der Zee J, BELNEU consortium (2013) Explorative genetic study of UBQLN2 and PFN1 in an extended Flanders-Belgian cohort of frontotemporal lobar degeneration patients. Neurobiol Aging 34, 1711.e1-1711.e5.

[109] Van Deerlin VM, Sleiman PM, Martinez-Lage M, ChenPlotkin A, Wang LS, Graff-Radford NR, Dickson DW, Rademakers R, Boeve BF, Grossman M, Arnold SE, Mann DM, Pickering-Brown SM, Seelaar H, Heutink P, van Swieten JC, Murrell JR, Ghetti B, Spina S, Grafman J, Hodges J, Spillantini MG, Gilman S, Lieberman AP, Kaye JA, Woltjer RL, Bigio EH, Mesulam M, Al-Sarraj S, Troakes C, Rosenberg RN, White CL 3rd, Ferrer I, Lladó A, Neumann M, Kretzschmar HA, Hulette CM, Welsh-Bohmer KA, Miller BL, Alzualde A, Lopez de Munain A, McKee AC, Gearing M, Levey AI, Lah JJ, Hardy J, Rohrer JD, Lashley T, Mackenzie IR, Feldman HH, Hamilton RL, Dekosky ST, van der Zee J, Kumar-Singh S, Van Broeckhoven C, Mayeux R, Vonsattel JP, Troncoso JC, Kril JJ, Kwok JB, Halliday GM, Bird TD, Ince PG, Shaw PJ, Cairns NJ, Morris JC, McLean CA, DeCarli C, Ellis WG, Freeman SH, Frosch MP, Growdon JH, Perl DP, Sano M, Bennett DA, Schneider JA, Beach TG, Reiman EM, Woodruff BK, Cummings J, Vinters HV, Miller CA, Chui HC, Alafuzoff I, Hartikainen P, Seilhean D, Galasko D, Masliah E, Cotman CW, Tuñón MT, Martínez MC, Munoz DG, Carroll SL, Marson D, Riederer PF, Bogdanovic N, Schellenberg GD, Hakonarson H, Trojanowski JQ, Lee VM. (2010). Common variants at $7 \mathrm{p} 21$ are associated with frontotemporal lobar degeneration with TDP-43 inclusions. Nat Genet 42, 234-239.

[110] Finch N, Carrasquillo MM, Baker M, Rutherford NJ, Coppola G, Dejesus-Hernandez M, Crook R, Hunter T, Ghidoni R, Benussi L, Crook J, Finger E, Hantanpaa KJ, Karydas AM, Sengdy P, Gonzalez J, Seeley WW, Johnson N, Beach TG, Mesulam M, Forloni G, Kertesz A, Knopman DS, Uitti R, White 3rd CL, Caselli R, Lippa C, Bigio EH, Wszolek ZK, Binetti G, Mackenzie IR, Miller
BL, Boeve BF, Younkin SG, Dickson DW, Petersen RC, Graff-Radford NR, Geschwind DH, Rademakers R (2011) TMEM106B regulates progranulin levels and the penetrance of FTLD in GRN mutation carriers. Neurology 76, 467-474.

[111] Cruchaga C, Graff C, Chiang HH, Wang J, Hinrichs AL, Spiegel N, Bertelsen S, Mayo K, Norton JB, Morris JC, Goate A (2011) Association of TMEM106B gene polymorphism with age at onset in granulin mutation carriers and plasma granulin protein levels. Arch Neurol 68, 581-586.

[112] Gallagher MD, Suh E, Grossman M, Elman L, McCluskey L, Van Swieten JC, Al-Sarraj S, Neumann M, Gelpi E, Ghetti B, Rohrer JD, Halliday G, Van Broeckhoven C, Seilhean D, Shaw PJ, Frosch MP, Alafuzoff I, Antonell A, Bogdanovic N, Brooks W, Cairns NJ, Cooper-Knock J, Cotman C, Cras P, Cruts M, De Deyn PP, DeCarli C, Dobson-Stone C, Engelborghs S, Fox N, Galasko D, Gearing M, Gijselinck I, Grafman J, Hartikainen P, Hatanpaa KJ, Highley JR, Hodges J, Hulette C, Ince PG, Jin LW, Kirby J, Kofler J, Kril J, Kwok JB, Levey A, Lieberman A, Llado A, Martin JJ, Masliah E, McDermott CJ, McKee A, McLean C, Mead S, Miller CA, Miller J, Munoz DG, Murrell J, Paulson H, Piguet O, Rossor M, Sanchez-Valle R, Sano M, Schneider J, Silbert LC, Spina S, van der Zee J, Van Langenhove T, Warren J, Wharton SB, White CL 3rd, Woltjer RL, Trojanowski JQ, Lee VM, Van Deerlin V, Chen-Plotkin AS (2014) TMEM106B is a genetic modifier of frontotemporal lobar degeneration with $\mathrm{C} 9$ orf 72 hexanucleotide repeat expansions. Acta Neuropathol 127, 407-418.

[113] van Blitterswijk M, Mullen B, Nicholson AM, Bieniek KF, Heckman MG, Baker MC, DeJesus-Hernandez M, Finch NA, Brown PH, Murray ME, Hsiung GY, Stewart $\mathrm{H}$, Karydas AM, Finger E, Kertesz A, Bigio EH, Weintraub S, Mesulam M, Hatanpaa KJ, White CL 3rd, Strong MJ, Beach TG, Wszolek ZK, Lippa C, Caselli R, Petrucelli L, Josephs KA, Parisi JE, Knopman DS, Petersen RC, Mackenzie IR, Seeley WW, Grinberg LT, Miller BL, Boylan KB, Graff-Radford NR, Boeve BF, Dickson DW, Rademakers R (2014) TMEM106B protects C9ORF72 expansion carriers against frontotemporal dementia. Acta Neuropathol 127, 397-406.

[114] Brady OA, Zheng Y, Murphy K, Huang M, Hu F (2013) The frontotemporal lobar degeneration risk factor, TMEM106B, regulates lysosomal morphology and function. Hum Mol Genet 22, 685-695.

[115] Rollinson S, Rohrer JD, van der Zee J, Sleegers K, Mead S, Engelborghs S, Collinge J, De Deyn PP, Mann DM, Van Broeckhoven C, Pickering-Brown SM (2011) No association of PGRN 30UTR rs5848 in frontotemporal lobar degeneration. Neurobiol Aging 32, 754-755.

[116] Ferrari R, Hernandez DG, Nalls MA, Rohrer JD, Ramasamy A, Kwok JB, Dobson-Stone C, Brooks WS, Schofield PR, Halliday GM, Hodges JR, Piguet O, Bartley L, Thompson E, Haan E, Hernández I, Ruiz A, Boada M, Borroni B, Padovani A, Cruchaga C, Cairns NJ, Benussi L, Binetti G, Ghidoni R, Forloni G, Galimberti D, Fenoglio C, Serpente M, Scarpini E, Clarimón J, Lleó A, Blesa R, Waldö ML, Nilsson K, Nilsson C, Mackenzie IR, Hsiung GY, Mann DM, Grafman J, Morris CM, Attems J, Griffiths TD, McKeith IG, Thomas AJ, Pietrini P, Huey ED, Wassermann EM, Baborie A, Jaros E, Tierney MC, Pastor P, Razquin C, Ortega-Cubero S, Alonso E, Perneczky R, Diehl-Schmid J, Alexopoulos P, Kurz A, Rainero I, Rubino 
E, Pinessi L, Rogaeva E, St George-Hyslop P, Rossi G, Tagliavini F, Giaccone G, Rowe JB, Schlachetzki JC, Uphill J, Collinge J, Mead S, Danek A, Van Deerlin VM, Grossman M, Trojanowski JQ, van der Zee J, Deschamps W, Van Langenhove T, Cruts M, Van Broeckhoven C, Cappa SF, Le Ber I, Hannequin D, Golfier V, Vercelletto M, Brice A, Nacmias B, Sorbi S, Bagnoli S, Piaceri I, Nielsen JE, Hjermind LE, Riemenschneider M, Mayhaus M, Ibach B, Gasparoni G, Pichler S, Gu W, Rossor MN, Fox NC, Warren JD, Spillantini MG, Morris HR, Rizzu P, Heutink P, Snowden JS, Rollinson S, Richardson A, Gerhard A, Bruni AC, Maletta R, Frangipane F, Cupidi C, Bernardi L, Anfossi M, Gallo M, Conidi ME, Smirne N, Rademakers R, Baker M, Dickson DW, Graff-Radford NR, Petersen RC, Knopman D, Josephs KA, Boeve BF, Parisi JE, Seeley WW, Miller BL, Karydas AM, Rosen H, van Swieten JC, Dopper EG, Seelaar H, Pijnenburg YA, Scheltens P, Logroscino G, Capozzo R, Novelli V, Puca AA, Franceschi M, Postiglione A, Milan G, Sorrentino P, Kristiansen M, Chiang HH, Graff C, Pasquier F, Rollin A, Deramecourt V, Lebert F, Kapogiannis D, Ferrucci L, Pickering-Brown S, Singleton AB, Hardy J, Momeni P (2014) Frontotemporal dementia and its subtypes: A genome-wide association study. Lancet Neurol 13, 686-699.

[117] Egger G, Liang G, Aparicio A, Jones PA (2004) Epigenetics in human disease and prospects for epigenetic therapy. Nature 429, 457-463.

[118] Goll MG, Bestor TH (2005) Eukaryotic cytosine methyltransferases. Апnи Rev Biochem 74, 481-514.

[119] Okano M, Bell DW, Haber, DA, Li E (1999) DNA methyltransferases Dnmt3a and Dnmt3b are essential for de novo methylation and mammalian development. Cell 99, 247257.

[120] Klose RJ, Bird AP (2006) Genomic DNA methylation: The mark and its mediators. Trends Biochem Sci 31, 89-97.

[121] Weber M, Schübeler D (2007) Genomic patterns of DNA methylation: Targets and function of an epigenetic mark. Curr Opin Cell Biol 19, 273-280.

[122] Guo JU, Su Y, Shin JH, Shin J, Li H, Xie B, Zhong C, Hu S, Le T, Fan G, Zhu H, Chang Q, Gao Y, Ming GL, Song H (2013) Distribution, recognition and regulation of non-CpG methylation in the adult mammalian brain. Nat Neurosci 17, 215-222.

[123] West RL, Lee JM, Maroun LE (1995) Hypomethylation of the amyloid precursor protein gene in the brain of an Alzheimer's disease patient. J Mol Neurosci 6, 141-146.

[124] Mastroeni D, Grover A, Delvaux E, Whiteside C, Coleman PD, Rogers J (2010) Epigenetic changes in Alzheimer's disease: Decrements in DNA methylation. Neurobiol Aging 31, 2025-2037.

[125] Chen KL, Wang SS, Yang YY, Yuan RY, Chen RM, Hu CJ (2009) The epigenetic effects of amyloid-beta(1-40) on global DNA and neprilysin genes in murine cerebral endothelial cells. Biochem Biophys Res Commun 378, 57-61.

[126] De Jager PL, Srivastava G, Lunnon K, Burgess J, Schalkwyk LC, Yu L, Eaton ML, Keenan BT, Ernst J, McCabe C, Tang A, Raj T, Replogle J, Brodeur W, Gabriel S, Chai HS, Younkin C, Younkin SG, Zou F, Szyf M, Epstein $\mathrm{CB}$, Schneider JA, Bernstein BE, Meissner A, ErtekinTaner N, Chibnik LB, Kellis M, Mill J, Bennett DA (2014) Alzheimer's disease: Early alterations in brain DNA methylation at ANK1, BIN1, RHBDF2 and other loci. Nat Neurosci 17, 1156-1163.
[127] Tohgi H, Utsugisawa K, Nagane Y, Yoshimura M, Ukitsu M, Genda Y (1999) The methylation status of cytosines in a tau gene promoter region alters with age to downregulate transcriptional activity in human cerebral cortex. Neurosci Lett 275, 89-92.

[128] Bollati V, Galimberti D, Pergoli L, Dalla Valle E, Barretta F, Cortini F, Scarpini E, Bertazzi PA, Baccarelli A (2011) DNA methylation in repetitive elements and Alzheimer disease. Brain Behav Immun 25, 1078-1083.

[129] Banzhaf-Strathmann J, Claus R, Mucke O, Rentzsch K, van der Zee J, Engelborghs S, De Deyn PP, Cruts M, van Broeckhoven C, Plass C, Edbauer D (2013) Promoter DNA methylation regulates progranulin expression and is altered in FTLD. Acta Neuropathol Commun $1,16$.

[130] Galimberti D, D'Addario C, Dell'osso B, Fenoglio C, Marcone A, Cerami C, Cappa SF, Palazzo MC, Arosio B, Mari D, Maccarrone M, Bresolin N, Altamura AC, Scarpini E (2013) Progranulin gene (GRN) promoter methylation is increased in patients with sporadic frontotemporal lobar degeneration. Neurol Sci 34, 899-903.

[131] Li Y, Chen JA, Sears RL, Gao F, Klein ED, Karydas A, Geschwind MD, Rosen HJ, Boxer AL, Guo W, Pellegrini M, Horvath S, Miller BL, Geschwind DH, Coppola $G$ (2014) An epigenetic signature in peripheral blood associated with the haplotype on $17 \mathrm{q} 21.31$, a risk factor for neurodegenerative tauopathy. PLoS Genet 10, e1004211.

[132] Xi Z, van Blitterswijk M, Zhang M, McGoldrick P, McLean JR, Yunusova Y, Knock E, Moreno D, Sato C, McKeever P, Schneider R, Keith J, Petrescu N, Fraser P, Tartaglia MC, Baker MC, Graff-Radford NR, Boylan KB, Dickson DW, Mackenzie IR, Rademakers R, Robertson J, Zinman L, Rogaeva E (2015) Jump from pre-mutation to pathologic expansion in C9orf72. Am J Hum Genet 96, 962-970.

[133] Xi Z, Rainero I, Rubino E, Pinessi L, Bruni AC, Maletta RG, Nacmias B, Sorbi S, Galimberti D, Surace EI, Zheng Y, Moreno D, Sato C, Liang Y, Zhou Y, Robertson J, Zinman L, Tartaglia MC, St George-Hyslop P, Rogaeva E (2014) Hypermethylation of the CpG-island near the C9orf72 $\mathrm{G}(4) \mathrm{C}(2)$-repeat expansion in FTLD patients. Hum Mol Genet 23, 5630-5637.

[134] Xi Z, Zhang M, Bruni AC, Maletta RG, Colao R, Fratta P, Polke JM, Sweeney MG, Mudanohwo E, Nacmias B, Sorbi S, Tartaglia MC, Rainero I, Rubino E, Pinessi L, Galimberti D, Surace EI, McGoldrick P, McKeever P, Moreno D, Sato C, Liang Y, Keith J, Zinman L, Robertson J, Rogaeva E (2015) The C9orf72 repeat expansion itself is methylated in ALS and FTLD patients. Acta Neuropathol 129, 715-727.

[135] Amaral PP, Dinger ME, Mercer TR, Mattick JS (2008) The eukaryotic genome as an RNA machine. Science 319, 1787-1789.

[136] Derrien T, Johnson R, Bussotti G, Tanzer A, Djebali S, Tilgner H, Guernec G, Martin D, Merkel A, Knowles DG, Lagarde J, Veeravalli L, Ruan X, Ruan Y, Lassmann T, Carninci P, Brown JB, Lipovich L, Gonzalez JM, Thomas M, Davis CA, Shiekhattar R, Gingeras TR, Hubbard TJ, Notredame C, Harrow J, Guigó R (2012) The GENCODE v7 catalog of human long noncoding RNAs: Analysis of their gene structure, evolution, and expression. Genome Res 22, 1775-1789.

[137] Bernstein E, Allis CD (2005). RNA meets chromatin. Genes Dev 19, 1635-1655. 
[138] Hwang H-W, Mendell JT (2006) MicroRNAs in cell proliferation, cell death, and tumorigenesis. Br J Cancer $\mathbf{9 4 ,}$ 776-780.

[139] Sevignani C, Calin GA, Siracusa LD, Croce CM (2006) Mammalian microRNAs: A small world for fine-tuning gene expression. Mamm Genome 17, 189-202.

[140] Chang T-C, Mendell JT (2007) MicroRNAs in vertebrate physiology and human disease. Annu Rev Genomics Hum Genet 8, 215-239.

[141] Fabbri M, Ivan M, Cimmino A, Negrini M, Calin GA (2007) Regulatory mechanisms of microRNAs involvement in cancer. Expert Opin Biol Ther 7, 1009-1019.

[142] Belzil VV, Gendron TF, Petrucelli L (2013) RNAmediated toxicity in neurodegenerative disease. Mol Cell Neurosci 56, 406-419.

[143] Lau P, Bossers K, Janky R, Salta E, Frigerio CS, Barbash S, Rothman R, Sierksma AS, Thathiah A, Greenberg D, Papadopoulou AS, Achsel T, Ayoubi T, Soreq H, Verhaagen J, Swaab DF, Aerts S, De Strooper B (2013) Alteration of the microRNA network during the progression of Alzheimer's disease. EMBO Mol Med 5, 1613-1634.

[144] Galimberti D, Villa C, Fenoglio C, Serpente M, Ghezzi L, Cioffi SM, Arighi A, Fumagalli G, Scarpini E (2014) Circulating miRNAs as potential biomarkers in Alzheimer's disease. J Alzheimers Dis 42, 1261-1267.

[145] Fenoglio C, Ridolfi E, Galimberti D, Scarpini E (2013) An emerging role for long non-coding RNA dysregulation in neurological disorders. Int J Mol Sci 14, 20427-20442.

[146] Prensner JR, Chinnaiyan AM (2011) The emergence of IncRNAs in cancer biology. Cancer Discov 1, 391-407.

[147] Faghihi MA, Modarresi F, Khalil AM, Wood DE, Sahagan BG, Morgan TE, Finch CE, St Laurent 3rd G, Kenny PJ, Wahlestedt C (2008) Expression of a noncoding
RNA is elevated in Alzheimer's disease and drives rapid feed-forward regulation of beta-secretase. Nat Med 14, 723-730.

[148] Mus E, Hof PR, Tiedge H (2007) Dendritic BC200 RNA in aging and in Alzheimer's disease. Proc Natl Acad Sci U S A 104, 10679-10684.

[149] Bernard D, Prasanth KV, Tripathi V, Colasse S, Nakamura T, Xuan Z, Zhang MQ, Sedel F, Jourdren L, Coulpier F, Triller A, Spector DL, Bessis A (2010) A long nuclearretained non-coding RNA regulates synaptogenesis by modulating gene expression. EMBO J 29, 3082-3093.

[150] Tripathi V, Ellis JD, Shen Z, Song DY, Pan Q, Watt AT, Freier SM, Bennett CF, Sharma A, Bubulya PA, Blencowe BJ, Prasanth SG, Prasanth KV (2010) The nuclear-retained noncoding RNA MALAT1 regulates alternative splicing by modulating SR splicing factor phosphorylation. $\mathrm{Mol}$ Cell 39, 925-938.

[151] Dieker J, Muller S (2010) Epigenetic histone code and autoimmunity. Clin Rev Allergy Immunol 39, 78-84.

[152] Brooks WH, Le Dantec C, Pers JO, Youinou P, Renaudineau Y (2010) Epigenetics and autoimmunity. J Autoimmun 34, J207-J219.

[153] Zhang K, Schrag M, Crofton A, Trivedi R, Vinters H, Kirsch W (2012) Targeted proteomics for quantification of histone acetylation in Alzheimer's disease. Proteomics 12, 1261-1268.

[154] Marques S, Lemos R, Ferreiro E, Martins M, de Mendonca A, Santana I, Outeiro T, Pereira C (2012) Epigenetic regulation of BACE1 in Alzheimer's disease patients and in transgenic mice. Neuroscience 220, 256-266.

[155] Araki Y, Mimura T (2017) The histone modification code in the pathogenesis of autoimmune diseases. Mediators Inflamm 2017, 2608605. 